\title{
Recent retreat of major outlet glaciers on Novaya Zemlya, Russian Arctic, influenced by fjord geometry and sea-ice conditions
}

\author{
J. Rachel CARR, ${ }^{1}$ Chris STOKES, ${ }^{1}$ Andreas VIELI ${ }^{2}$ \\ ${ }^{1}$ Department of Geography, Durham University, Durham, UK \\ E-mail: j.r.carr@durham.ac.uk \\ ${ }^{2}$ Department of Geography, University of Zürich, Zürich, Switzerland
}

\begin{abstract}
Substantial ice loss has occurred in the Russian High Arctic during the past decade, predominantly on Novaya Zemlya, yet the region has been studied relatively little. Consequently, the factors forcing mass loss and the relative contribution of ice dynamics versus surface melt are poorly understood. Here we evaluate the influence of atmospheric/oceanic forcing and variations in fjord width on the behaviour of 38 glaciers on the northern ice cap, Novaya Zemlya. We compare retreat rates on land- versus marine-terminating outlets and on the Kara versus Barents Sea coasts. Between 1992 and $2010,90 \%$ of the study glaciers retreated and retreat rates were an order of magnitude higher for marine-terminating outlets $\left(52.1 \mathrm{~m} \mathrm{a}^{-1}\right)$ than for land-terminating glaciers $\left(4.8 \mathrm{~m} \mathrm{a}^{-1}\right)$. We identify a post-2000 acceleration in marine-terminating glacier retreat, which corresponded closely to changes in sea-ice concentrations. Retreat rates were higher on the Barents Sea coast, which we partly attribute to lower sea-ice concentrations, but varied dramatically between individual glaciers. We use empirical data to categorize changes in along-flow fjord width, and demonstrate a significant relationship between fjord width variability and retreat rate. Results suggest that variations in fjord width exert a major influence on glacier retreat.
\end{abstract}

KEYWORDS: Arctic glaciology, atmosphere/ice/ocean interactions, climate change, ice dynamics, remote sensing

\section{INTRODUCTION}

Glaciers and ice caps have dominated the recent cryospheric contribution to sea-level rise, and losses are forecast to continue during the 21 st century (Meier and others, 2007; Solomon and others, 2007; Gardner and others, 2013). In recent years, substantial mass deficits have been documented in the major Arctic archipelagos, including the Russian Arctic (Sharov and others, 2009; Kotlyakov and others, 2010; Moholdt and others, 2012), Svalbard (Moholdt and others, 2010; Nuth and others, 2010) and the Canadian Arctic (Gardner and others, 2011, 2012; Lenaerts and others, 2013), highlighting their potential vulnerability to near-future warming. However, the mass budget of the Russian Arctic has received less scientific attention than other regions (Bassford and others, 2006) despite accounting for $20 \%$ of Arctic glaciation outside the Greenland ice sheet (GrlS) (Dowdeswell and others, 1997) and containing an estimated $17778 \mathrm{~km}^{3}$ of ice (Radić and others, 2013). Recent estimates from Ice, Cloud and land Elevation Satellite (ICESat) laser altimetry and Gravity Recovery and Climate Experiment (GRACE) gravimetry data suggest that the Russian Arctic lost mass at a rate between $9.1 \pm 2.0$ (Moholdt and others, 2012) and $11 \pm 4 \mathrm{Gt} \mathrm{a}^{-1}$ for the period 2003-09 (Gardner and others, 2013), equating to a sealevel rise between 0.025 and $0.033 \mathrm{~mm} \mathrm{a}^{-1}$. Novaya Zemlya (NVZ) was identified as the dominant source of this mass deficit, accounting for $80 \%$ of observed losses (Moholdt and others, 2012). Moreover, the Russian Arctic has been identified as a primary source of 21 st-century ice volume loss using surface mass-balance modelling, with the estimated contribution ranging between $20 \pm 8$ and $28 \pm 8 \mathrm{~mm}$ sea-level equivalent (SLE) (Radić and others, 2013).
Evidence from the GrIS (e.g. Howat and others, 2008; Rignot and others, 2008; Moon and others, 2012; Enderlin and Howat, 2013; Nick and others, 2013) and other Arctic ice masses (Burgess and Sharp, 2008) has highlighted changes in marine-terminating outlet glacier dynamics as a key contributor to contemporary mass deficits and the response of Arctic ice masses to climate change. This dynamic response can produce rapid mass loss via accelerated ice discharge, and currently accounts for $\sim 50 \%$ of the total mass loss from the Grls, with the remainder being attributed to negative surface mass balance (Van den Broeke and others, 2009). However, despite its potential importance, the dynamic component of mass loss from NVZ, and elsewhere in the Russian Arctic, is poorly quantified (Sharov, 2005). Studies suggest that marine-terminating outlet glaciers on NVZ retreated relatively rapidly $\left(>300 \mathrm{ma}^{-1}\right)$ during the first half of the 20th century, consistent with Little Ice Age warming (Zeeberg and Forman, 2001). However, there is substantial uncertainty over recent glacier behaviour, with some studies documenting glacier stabilization or moderate retreat between 1964 and 1993 (Zeeberg and Forman, 2001). In contrast, others record substantial reductions in both ice volume (Kotlyakov and others, 2010) and the length of ice coast (Sharov, 2005) between the 1950s and 2000s, and a reduction in the aerial extent of certain marine-terminating outlets by up to $5 \mathrm{~km}^{2}$ between about 1990 and 2000 (Kouraev and others, 2006). Furthermore, potential differences in the response of land- and marine-terminating glaciers on NVZ to recent forcing have not been extensively assessed. Moholdt and others (2012) reported no significant difference in frontal thinning rates on marine- and land-terminating outlets. This is similar to results from the Canadian Arctic (Gardner and others, 2011), but differs markedly from the 

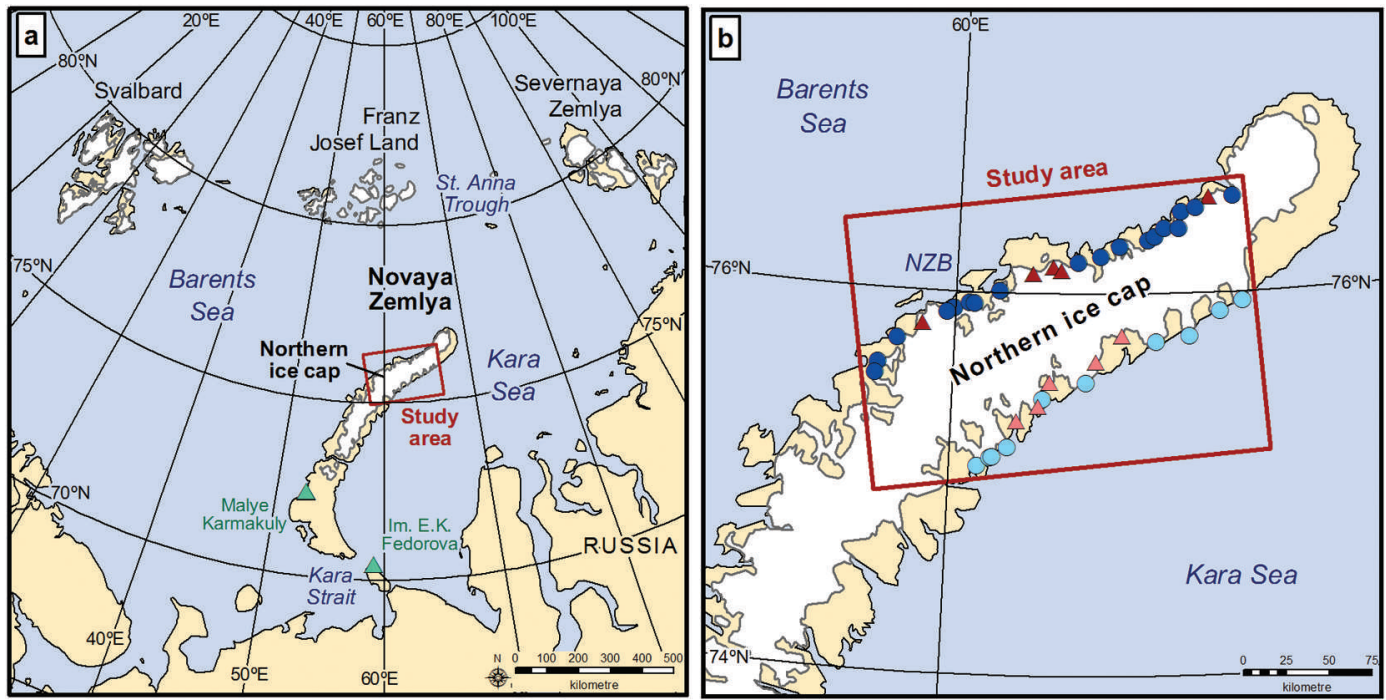

Fig. 1. Location map of Novaya Zemlya, showing the study area and glaciers studied. (a) Location of Novaya Zemlya and the northern ice cap within the Russian High Arctic. Location of study area (red box), meteorological stations (green triangles) and water masses are shown. (b) Location of Novaya Zemlya Bank (NZB) and glaciers studied, symbolized according to coast and terminus type as follows: Barents Sea marine-terminating (dark blue circles), Kara Sea marine-terminating (light blue circles), Barents Sea land-terminating (dark red triangles) and Kara Sea land-terminating (light red triangles).

GrlS, where thinning rates were far higher on marineterminating outlets than their land-terminating counterparts (Sole and others, 2008). Assessment of NVZ glacier behaviour in relation to atmospheric and oceanic forcing has also been limited in comparison with other Arctic regions, although evidence suggests that reduced retreat between the 1960s and 1990s coincided with decreased winter air temperatures, increased precipitation and elevated sea surface temperatures (SSTs) in the Barents Sea (Zeeberg and Forman, 2001). Large uncertainties therefore remain over the magnitude of contemporary glacier retreat on NVZ, its contribution to mass loss and the factors driving this behaviour.

Here we investigate frontal position variations on 38 outlet glaciers, located on the northern ice cap, NVZ (Fig. 1). We focus specifically on the northern ice cap because it contains all NVZ's major marine-terminating outlet glaciers and represents $95 \%$ of its total ice-covered area (Dowdeswell and Williams, 1997; Sharov, 2005). Our study glaciers comprise 10 land-terminating and 28 marine-terminating outlets, which enables us to explore the influence of terminus type on retreat rates (Figs 1 and 2). Furthermore, we assess differences between the Barents and Kara Sea coasts (Figs 1 and 2), which are characterized by different climatic, oceanic and topographic conditions (Kotlyakov, 1978, 2006; Zeeberg and Forman, 2001). The three glaciers previously observed during the active surge phase (Grant and others, 2009) were excluded from the assessment and represent $\sim 6 \%$ of the total number of marine-terminating outlet glaciers on the northern ice cap $(n=38)$. We first quantify NVZ outlet glacier retreat rates between 1992 and 2010, and assess changes in relation to terminus type and location. We then evaluate the influence of atmospheric and oceanic controls on frontal position change (the term 'oceanic' includes forcing associated with sea ice and SSTs). Subsurface ocean temperature data are very limited for NVZ and are therefore only discussed briefly. Finally, we investigate the influence of variations in fjord width and provide a new empirical framework for assessing its influence on glacier frontal position change.

\section{METHODS}

\subsection{Frontal position data}

Outlet glacier frontal positions were obtained primarily from synthetic aperture radar (SAR) image mode precision data. Imagery was supplied by the European Space Agency (ESA), acquired as part of the European Remote-sensing Satellite-1 (ERS-1), ERS-2 and Envisat missions. Following Carr and others (2013b), data were processed by applying precise orbital state vectors, and radiometric calibration was applied. Images were then multi-looked to reduce speckle and terrain-corrected using version 2 of the $30 \mathrm{~m}$ resolution Advanced Spaceborne Thermal Emission and Reflection Radiometer (ASTER) global digital elevation model (GDEM). Owing to the higher geolocation accuracy of the Envisat data, ERS images were co-registered with corresponding Envisat scenes. SAR imagery was supplemented with visible Landsat imagery where possible, which was provided by the United States Geological Survey (USGS) Global Visualization Viewer (http://glovis.usgs.gov/). For both imagery types, scenes were selected as close as possible to the end of the calendar month, to allow for comparison with monthly means of atmospheric and oceanic data. Landsat imagery was provided at a spatial resolution of $30 \mathrm{~m}$ and the SAR imagery was output with a cell size of $37.5 \mathrm{~m}$.

Frontal position variations were measured using a previously employed method, whereby the glacier terminus was repeatedly digitized within a fixed reference box (e.g. Moon and Joughin, 2008; Howat and others, 2010; McFadden and others, 2011; Carr and others, 2013b). The box was aligned approximately parallel to the ice-flow direction at the glacier terminus and extended from an arbitrary upstream reference line. The terminus was then digitized from successive images and the change in area was divided by the width to calculate the change in frontal position. Retreat rates were calculated relative to the frontal position between 24 June and 8 July 1992, with the exact date depending on data availability. Glaciers for which frontal positions were available for multiple images during 

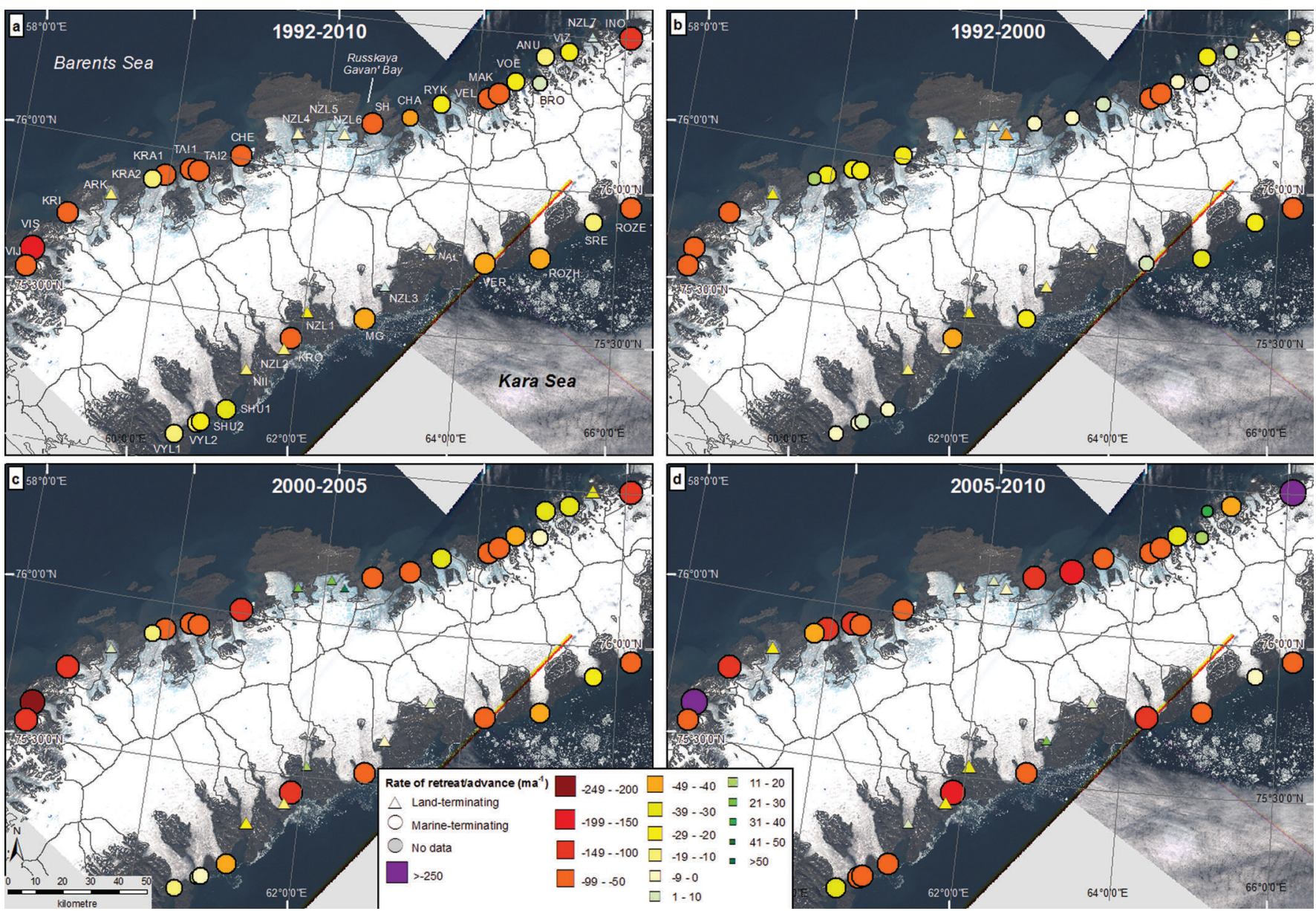

Fig. 2. Outlet glacier retreat rates on the northern ice cap, Novaya Zemlya, for the periods (a) 1992-2010, (b) 1992-2000, (c) 2000-05 and (d) 2005-10. Retreat rates are symbolized according to terminus type: land-terminating (triangles) and marine-terminating (circles). The magnitude of frontal position change is symbolized according to colour (purple through to yellow = retreat; greens $=$ advance) and symbol size (larger symbols = higher retreat rate). Note that the colour and size scales are nonlinear. Outlet glacier catchments are shown in dark grey: data were provided by G. Moholdt (2012) and are part of the Randolph Glacier Inventory (Arendt and others, 2012). Glacier abbreviations are derived from the World Glacier Inventory, where available, and split termini are numbered sequentially $(1=$ main terminus, $2=$ secondary terminus). Unnamed land-terminating glaciers were given the prefix ' $N Z L^{\prime}$ and numbered sequentially. Abbreviations of glacier names are as follows (from south to north): Barents Sea coast: VIJ: Vil'kitskogo Juz; VIS: Vil'kitskogo Sev.; KRI: Krivosheina; ARK: Arkhangelskolgu; KRA2: Kraynij 2; KRA1: Kraynij 1; TAI1: Taisija 1; TAI2: Taisija 2; CHE: Chernysheva; SH: Shokalskogo; CHA: Chaveva; RYK: Rykachova; VEL: Vel'Kena; MAK: Maka; VOE: Voejkova; BRO: Brounova; ANU: Anuchina; VIZ: Vize; and INO: Inostrantseva. Kara Sea coast: VYL1: Vylki 1; VYL2: Vylki 2; SHU2: Shury 2; SHU1: Shury 1; NII; Niiga; KRO: Kropotkina; MG: Moshnyj; NAL: Nalli; VER: Vershinskogo; ROZH: Rozhdestvenskogo; SRE: Srednij; and ROZE: Roze. (a) Location of study area and meteorological stations.

this time period showed no discernible change. We first calculated total retreat rates for the study period (19922010). We then divided the period into three approximately equal portions, within the constraints of data availability, in order to investigate changes in retreat rates over time. Retreat rates were therefore calculated for the time periods 1992-2000, 2000-05 and 2005-10. Frontal position data were obtained at a monthly to annual resolution, as image availability varied between glaciers.

The mean error in marine-terminating outlet glacier frontal position was evaluated by repeatedly digitizing 16 sections of rock coastline from a subsample of five ERS, five Envisat and five Landsat images, where there should be no discernible change in coastline position between scenes (Carr and others, 2013b). The resultant total mean error in frontal position was $25.3 \mathrm{~m}$ for marine outlets, which can be primarily attributed to manual digitizing errors and accounts for errors in image geolocation and co-registration. Frontal positions for land-terminating outlets are subject to an additional error source, which results from the comparative difficulty in identifying land-based termini from radar imagery, as the land-ice boundary is less distinct than the ocean-ice interface. Consequently, we assessed this additional error source by repeatedly digitizing the same termini from the same image, for a subsample of five ERS and five Envisat images. The resultant additional error was $67.8 \mathrm{~m}$ and the total error for land-terminating outlets was $72.4 \mathrm{~m}$.

\subsection{Atmospheric and oceanic data}

Atmospheric and oceanic data were obtained from a variety of sources and used to calculate seasonal and annual mean values for individual glaciers and for each coast. Surface air temperature data were obtained from Malye Karmakuly $\left(72^{\circ} 20^{\prime} 50^{\prime \prime} \mathrm{N}, 52^{\circ} 43^{\prime} 34^{\prime \prime} \mathrm{E}\right)$ and Im. E.K. Fedorova $\left(70^{\circ} 27^{\prime} 8^{\prime \prime} \mathrm{N}, 59^{\circ} 3^{\prime} 13^{\prime \prime} \mathrm{E}\right)$ meteorological stations (Fig. 1). Data were provided at a monthly temporal resolution by the Hydrometeorological Information, World Data Center Baseline Climatological Data Sets (http://meteo.ru/english/ climate/cl_data.php). Meteorological station data are sparse 
on NVZ, and Malye Karmakuly and Im. E.K. Fedorova are the only stations with sufficient data to assess interannual air temperature trends during the study period. However, these stations are located $\sim 400$ and $\sim 525 \mathrm{~km}$, respectively, from the study glaciers, and therefore we also used monthly air temperature data products from the US National Centers for Environmental Prediction/US National Center for Atmospheric Research (NCEP/NCAR) reanalysis 1 (Kalnay and others, 1996) and the European Centre for Medium-Range Weather Forecasts (ECMWF) Interim Re-analysis (ERAInterim) data (Dee and others, 2011).

NCEP/NCAR reanalysis data have a spatial resolution of $2.5^{\circ}$ (about $230 \mathrm{~km} \times 280 \mathrm{~km}$ at $76^{\circ} \mathrm{N}$ ) and were provided by the National Oceanic and Atmospheric Administration (NOAA)/Office of Oceanic and Atmospheric Research (OAR)/Earth and Space Research Laboratory (ESRL) Physical Sciences Division (PSD), Boulder, CO, USA (http://www.esrl. noaa.gov/psd/data/gridded/data.ncep.reanalysis.html). ERAInterim data were produced by the ECMWF and have a spatial resolution of $0.75^{\circ}$ (about $70 \mathrm{~km} \times 80 \mathrm{~km}$ at $76^{\circ} \mathrm{N}$ ). In both cases, we used air temperature data from the $700 \mathrm{hPa}$ geopotential height, as opposed to $2 \mathrm{~m}$ height, as these values correlate better with ground station data elsewhere in the Arctic (personal communication from A. Gardener, 2013) and limit the influence of SSTs on surface temperatures (Moholdt and others, 2012). Air temperature values were extracted from all grid squares containing the study glaciers, and mean annual and mean summer (June-August) values were calculated. The pattern of air temperature variation was very similar between the two data products, which were strongly correlated $(r=0.90, p<0.01)$, and differences in absolute values most likely result from their differing spatial resolution. Owing to the location of meteorological stations and the spatial resolution of the reanalysis data, differences in air temperatures between the Barents Sea and Kara Sea coasts could not be assessed.

Sea-ice data were obtained from the US National/Naval Ice Centre charts (http://www.natice.noaa.gov/), which are compiled from a range of data sources and have a spatial resolution of up to $50 \mathrm{~m}$. Data were sampled at each glacier terminus, within a polygon extending $50 \mathrm{~m}$ perpendicular to the terminus and along its entire width. Mean seasonal values were calculated for each coast by averaging data from all study glaciers on that coast. The standard deviation in mean monthly sea-ice concentrations was $0.67 \%$ on the Barents Sea coast and $2.34 \%$ on the Kara Sea coast. Coastal averages were also used to calculate the number of ice-free months per year.

SST data were obtained from version 2 of the Reynolds SST analysis dataset (Reynolds and others, 2007). The SST products have been developed using optimum interpolation of satellite, ship and buoy data, with correction for biases between in situ and satellite data. We use the monthly resolution product, which has a spatial resolution of $0.25^{\circ}$ $\left(\sim 23 \mathrm{~km} \times 28 \mathrm{~km}\right.$ at $\left.76^{\circ} \mathrm{N}\right)$ (Reynolds and others, 2007). SST values were extracted from the grid squares closest to the study glacier termini, to ensure that data were as representative as possible of conditions at the calving front. The data are used to investigate surface ocean temperatures and are not necessarily representative of deeper ocean conditions. The sea-ice field within the dataset was used to identify months with minimal sea-ice concentrations, as significant sea-ice coverage would result in incorrect SST values. Mean values were therefore calculated for July-September, as these months had minimal sea-ice concentrations on both coasts for all years.

\subsection{Glacier width, fjord geometry, catchment size and bathymetry}

Fjord width was measured perpendicular to the glacier flowline: lines were drawn perpendicular to the flowline, at intervals of $100 \mathrm{~m}$ from the upstream reference line, and width was measured where the lines intersected with the fjord walls at sea level, as determined from satellite imagery. Fjord width variability was quantified by digitizing both fjord walls at sea level from the most recent satellite image and calculating the length of each fjord wall between the least and most extensive frontal positions. These lengths were divided by the straight-line distance between their respective start and end points to give the width variation for each wall, and these values were used to calculate the mean fjord width variability. Consequently, a fjord width variability value of 1 would indicate a fjord with straight walls, while higher values indicate a fjord with greater variability in width. Width variability was only calculated for glaciers with continuous fjord walls and not for those that retreated across sections of open water (e.g. between two islands). Qualitative categories of along-flow variation in fjord width during retreat were defined using satellite imagery and frontal position data from all our study glacier fjords. We identified eight different categories of fjord shape on NVZ, which are shown in the top panel of Figure 3. The penultimate category gives the percentage of the glacier front that terminates on land. The final category identifies glaciers that appear to have bathymetric pinning points, either in the form of rock islands visible at the terminus or a pattern of retreat which suggests that bathymetric highs are present. This initial assessment has been carried out on the basis of visible satellite imagery and is not discussed extensively because of the lack of detailed bathymetric data.

Catchments were provided by G. Moholdt and form part of the global Randolph Glacier Inventory project (Arendt and others, 2012). Catchments were manually digitized from satellite imagery obtained between 2000 and 2010 during the summer. Spot 5 stereoscopic survey of Polar Ice: Reference Images and Topographies (SPIRIT) scenes (Korona and others, 2009) were the primary data source for NVZ and were supplemented with Landsat data. We verified the catchment data against Landsat and radar imagery, and catchments containing multiple termini (e.g. KRA1 and KRA2) were not included when testing for a statistical relationship between catchment size and retreat rate. Regional bathymetry was assessed using 1:200000 scale topographic maps dating from 1974 and provided by www.topmap.narod.ru. Maps were georeferenced for comparison with other data sources.

\subsection{Statistical analysis}

Regression analysis was used to assess whether there was a significant difference between mean retreat rates on marineand land-terminating outlets and between the Kara and Barents Sea coasts for the period 1992-2010. The data were divided into four groups: (1) land-Kara, (2) marine-Kara, (3) land-Barents and (4) marine-Barents. For each group, we plotted relative frontal position against time (Fig. 4) and fitted a series of curves of varying complexity to each group of data: quadratic, fractional polynomial, cubic spline and lowess smoothing. This was done to assess whether the 


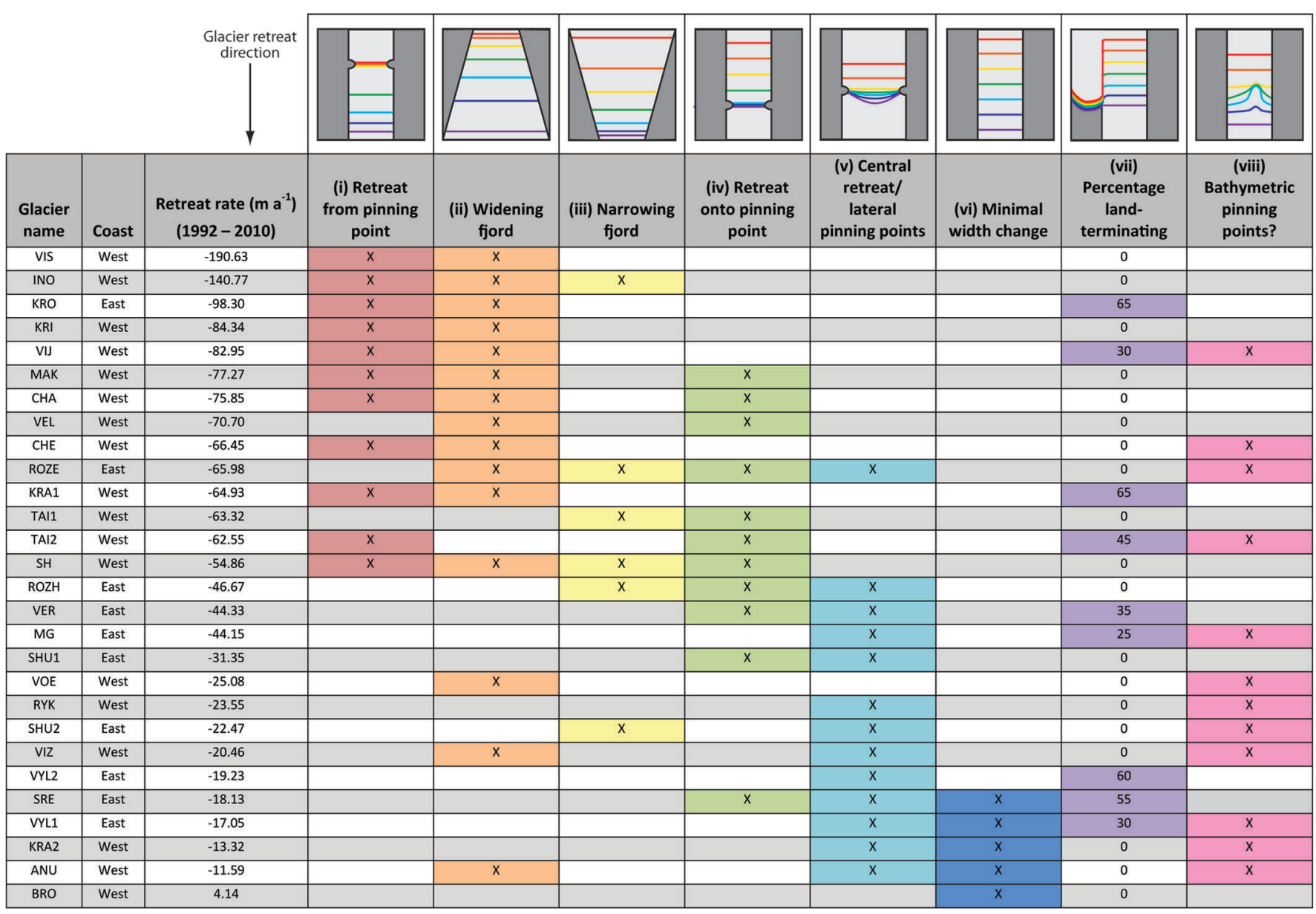

Fig. 3. Categorization of fjord width change in relation to total glacier retreat rate (1992-2010). Top row shows idealized cartoons of frontal position change in relation to changes in fjord width during retreat, going from the oldest measurement (red) to the most recent (purple). For each glacier, the types of width change observed during retreat are marked with an ' $x$ '. The percentage of the glacier that terminates on land is given in the penultimate column. Frontal retreat indicative of bathymetric pinning points is recorded in the final column. The information is ordered according to glacier retreat rate (1992-2010) from highest to lowest (column 3).

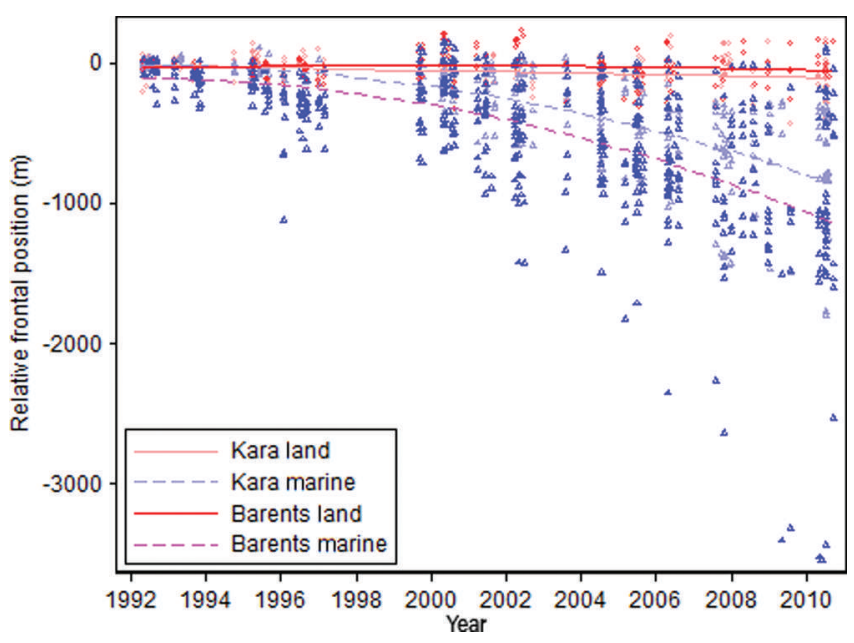

Fig. 4. Regression model for relative frontal position against time. Quadratic curves and individual data points are shown for each group. Data points are colour-coded as follows: Barents Sea marine-terminating (dark blue triangles), Kara Sea marine-terminating (light blue triangles), Barents Sea land-terminating (dark red triangles), Kara Sea land-terminating (light red triangles). The overall $R^{2}$ value for the regression model was 0.51 . choice of curve resulted in a significant change in the goodness fit of the curve to the data. The goodness of fit varied little with the choice of curve, and a quadratic curve was therefore used. To further assess the goodness of fit, the residuals for each group were plotted and no pattern was apparent, suggesting that the quadratic functions adequately describe the curve of the data.

In the first regression model, we regressed frontal position against time for each of the four groups using a quadratic function (Fig. 4). The overall $R^{2}$ value for the model was 0.51 and the root-mean-square error (RMSE) was $318 \mathrm{~m}$. These values apply to the model as a whole and include all four curves: the $R^{2}$ value is a measure of how well the four curves together describe their respective groups of data, and the RMSE value describes how far, on average, a given point would lie from its curve. Output from the model, specifically the $t$ and $p>|t|$ values, were used to compare the curve for land-Kara with the curves for the other three groups for each component of the quadratic equation (Table 1). The quadratic equation can be written in the form

$$
Y=b_{0}+b_{1} X+b_{2} x^{2}
$$

Following this, the first set of $t$ and $p>|t|$ values refer to $B_{0}$ (i.e. the intercept), the second set to $B_{1}$ (i.e. the slope) and the third to $B_{2}$ (i.e. the curvature). The $t$ value is calculated by dividing the coefficient by the standard error, and tests 


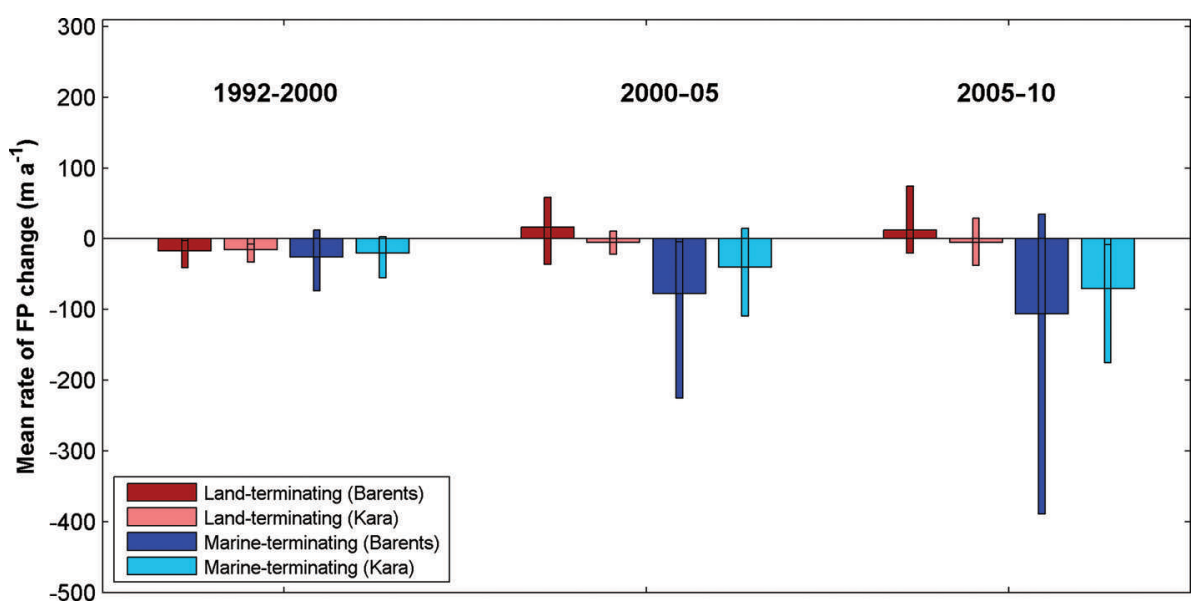

Fig. 5. Mean retreat rates for study glaciers on the northern ice cap, Novaya Zemlya. Retreat rates are calculated for three time periods: 1992-2000, 2000-05 and 2005-10. Retreat rates are calculated separately for marine- and land-terminating glaciers and for glaciers located on the Kara and Barents Sea coasts of Novaya Zemlya. Thick bars show mean rate of frontal position change for each category, and thin bars show the range (minimum-maximum) of values.

whether the coefficient is significantly different from zero, given the variability in the data. The value $p>|t|$ tests the probability of obtaining a value that is at least as extreme as the observed value if the null hypothesis is true (i.e. the coefficient value is zero). We use a $p>|t|$ value of 0.05 (i.e. a $95 \%$ confidence interval), meaning that a given coefficient is significantly different from zero when the $p>|t|$ value is $<0.05$. An additional regression model was then used to compare marine-Barents with marine-Kara data, in order to assess whether there was a significant difference in marineterminating outlet glacier retreat rates between the two coasts (Table 2).

Table 1. Regression model of glacier retreat over time using quadratic curves and grouping data according to coast and terminus type. The first three rows show the model output for the land-Kara group for each component of the quadratic equation. The subsequent outputs compare the curves for each data group with land-Kara for each component of the regression model $\left(B_{0}, B_{1}\right.$ and $B_{2}$ ). The 'coefficient' gives the value for predicting the dependent variable from the independent variable, and 'standard error' provides the standard errors associated with the coefficients. ' $t$ ' tests whether the coefficient is significantly different from zero and is calculated by (coefficient/standard error). $p>|t|$ gives two-tailed $p$-values which test the probability of getting a value as great as, or greater than, the observed value if the null hypothesis is true (i.e. the coefficient value is zero). A $p>|t|$ value of 0.05 was used to identify results that were statistically significant, which are in bold

\begin{tabular}{lccccc}
\hline & Group & Coefficient & Std error & $t$ & $p>|t|$ \\
\hline Intercept $\left(B_{0}\right)$ & & -51.69 & 33.39 & -1.55 & 0.12 \\
Date $\left(B_{1}\right)$ & & -0.01 & 0.01 & -1.28 & 0.20 \\
$\operatorname{Date}^{2}\left(B_{2}\right)$ & & $-2.6 \times 10^{-8}$ & $5.52 \times 10^{-6}$ & 0.00 & 0.99 \\
$\left.\operatorname{Group}^{(} B_{0}\right)$ & land-Barents & 33.00 & 48.04 & 0.69 & 0.49 \\
& marine-Barents & -246.35 & 39.12 & $\mathbf{- 6 . 3}$ & $\mathbf{0 . 0 0}$ \\
& marine-Kara & -116.36 & 45.63 & $\mathbf{- 2 . 5 5}$ & $\mathbf{0 . 0 1}$ \\
Group, & land-Barents & 0.013 & 0.02 & 0.78 & 0.43 \\
Date $\left(B_{1}\right)$ & marine-Barents & -0.12 & 0.01 & $\mathbf{- 8 . 5 9}$ & $\mathbf{0 . 0 0}$ \\
& marine-Kara & -0.09 & 0.02 & $\mathbf{- 6 . 1 1}$ & $\mathbf{0 . 0 0}$ \\
Group, & land-Barents & $-2.10 \times 10^{-6}$ & $8.47 \times 10^{-6}$ & -0.25 & 0.81 \\
Date $^{2}\left(B_{2}\right)$ & marine-Barents & $-2.2 \times 10^{-5}$ & $6.60 \times 10^{-6}$ & $\mathbf{- 3 . 3 4}$ & $\mathbf{0 . 0 0}$ \\
& marine-Kara & $-1.8 \times 10^{-5}$ & $7.35 \times 10^{-6}$ & $\mathbf{- 2 . 4 6}$ & $\mathbf{0 . 0 1}$ \\
& & & & &
\end{tabular}

\section{RESULTS}

\subsection{Frontal position}

Between 1992 and 2010, 90\% of the study glaciers underwent net retreat (Fig. 2). During this period, retreat rates were an order of magnitude greater on marine-terminating outlets $\left(51.2 \mathrm{~m} \mathrm{a}^{-1}\right)$ than on land-terminating outlets $\left(4.8 \mathrm{~m} \mathrm{a}^{-1}\right)$ (Figs 4 and 5). Retreat rates on land-terminating outlets were therefore comparable with error values: the mean frontal position error was $72.4 \mathrm{~m}$, which equates to an error in retreat rate of $4.0 \mathrm{~m} \mathrm{a}^{-1}$ for the period 1992-2010. Our results also show that mean retreat rates for marine-terminating outlets were significantly higher on the Barents Sea coast $\left(61.7 \mathrm{~m} \mathrm{a}^{-1}\right)$ than on the Kara Sea coast $\left(40.8 \mathrm{~m} \mathrm{a}^{-1}\right)$ during the study period (Figs 2 and 4). Although the pattern of retreat was similar for glaciers located on the same coast, the magnitude and rate of retreat varied markedly between individual glaciers (Figs 2 and 4). Indeed, neighbouring glaciers demonstrated very different retreat rates. This was most marked on Vil'kitskogo Sev. (VIS) and Vil'kitskogo Juz (VIJ), where retreat rates for the period 2005-10 averaged $343.9 \mathrm{~m} \mathrm{a}^{-1}$ on VIS compared with $84.6 \mathrm{~m} \mathrm{a}^{-1}$ on neighbouring VIJ (Fig. 2).

Seasonal frontal position variations on marine-terminating outlets were of the order of $100 \mathrm{~m}$ and were only distinguishable where high temporal resolution data were available (Fig. 6a). Seasonal variations were comparable

Table 2. Same as Table 1, but including only the marine-Kara and marine-Barents groups in the regression model

\begin{tabular}{|c|c|c|c|c|c|}
\hline & Group & Coefficient & Std error & $t$ & $p>|t|$ \\
\hline Intercept $\left(B_{0}\right)$ & & -168.05 & 37.93 & -4.43 & 0.00 \\
\hline Date $\left(B_{1}\right)$ & & -0.11 & 0.01 & -8.16 & 0.00 \\
\hline Date $^{2}\left(B_{2}\right)$ & & -0.00 & $5.92 \times 10^{-6}$ & -3.06 & 0.002 \\
\hline Group $\left(B_{0}\right)$ & marine-Barents & -129.00 & 45.36 & -2.87 & 0.004 \\
\hline $\begin{array}{l}\text { Group, } \\
\text { Date }\left(B_{1}\right)\end{array}$ & marine-Barents & -0.02 & 0.02 & -1.44 & 0.15 \\
\hline $\begin{array}{l}\text { Group, } \\
\text { Date }^{2}\left(B_{2}\right)\end{array}$ & marine-Barents & $-3.94 \times 10^{-6}$ & $7.38 \times 10^{-6}$ & -0.53 & 0.593 \\
\hline
\end{tabular}


Barents Sea coast
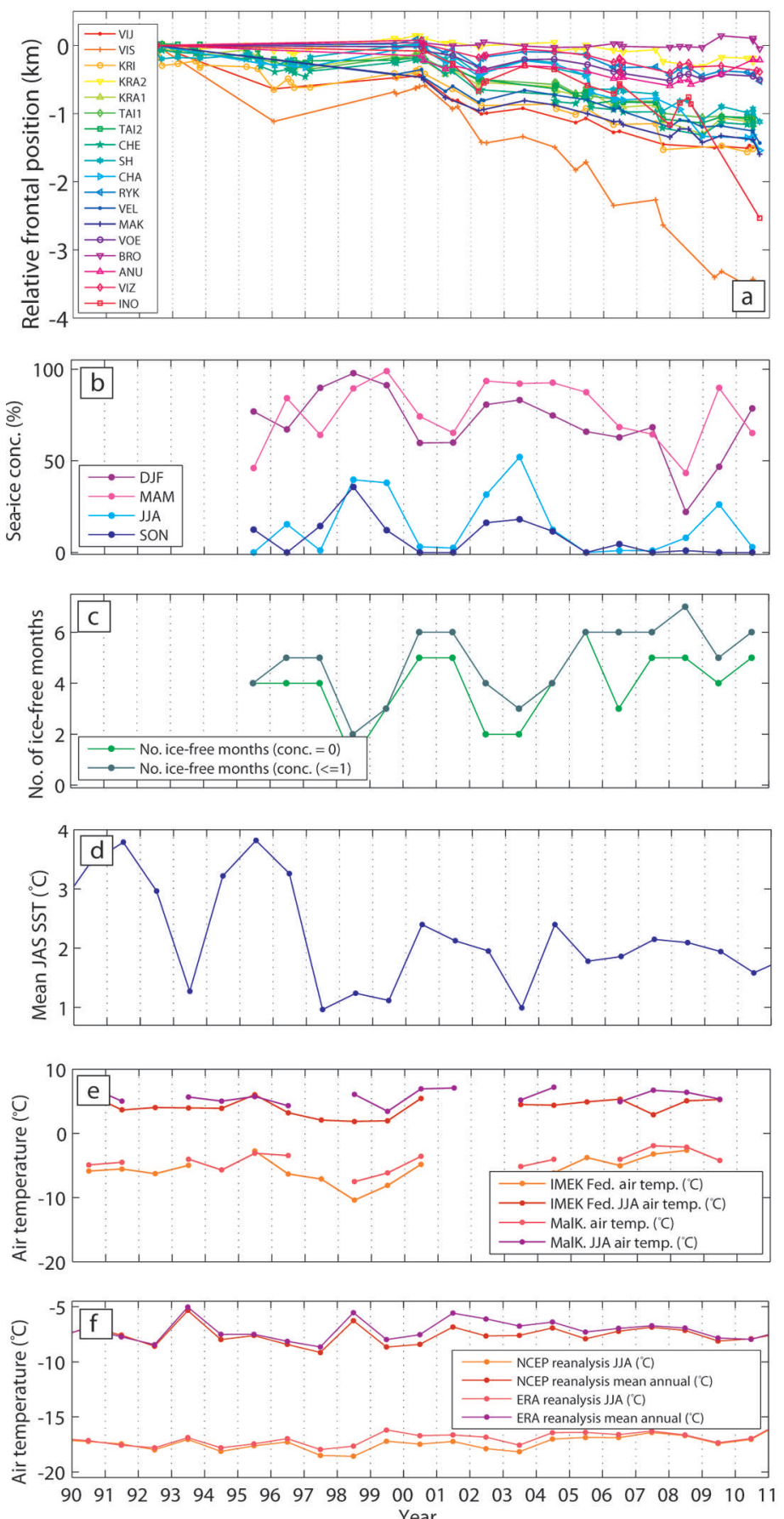

Year
Kara Sea coast
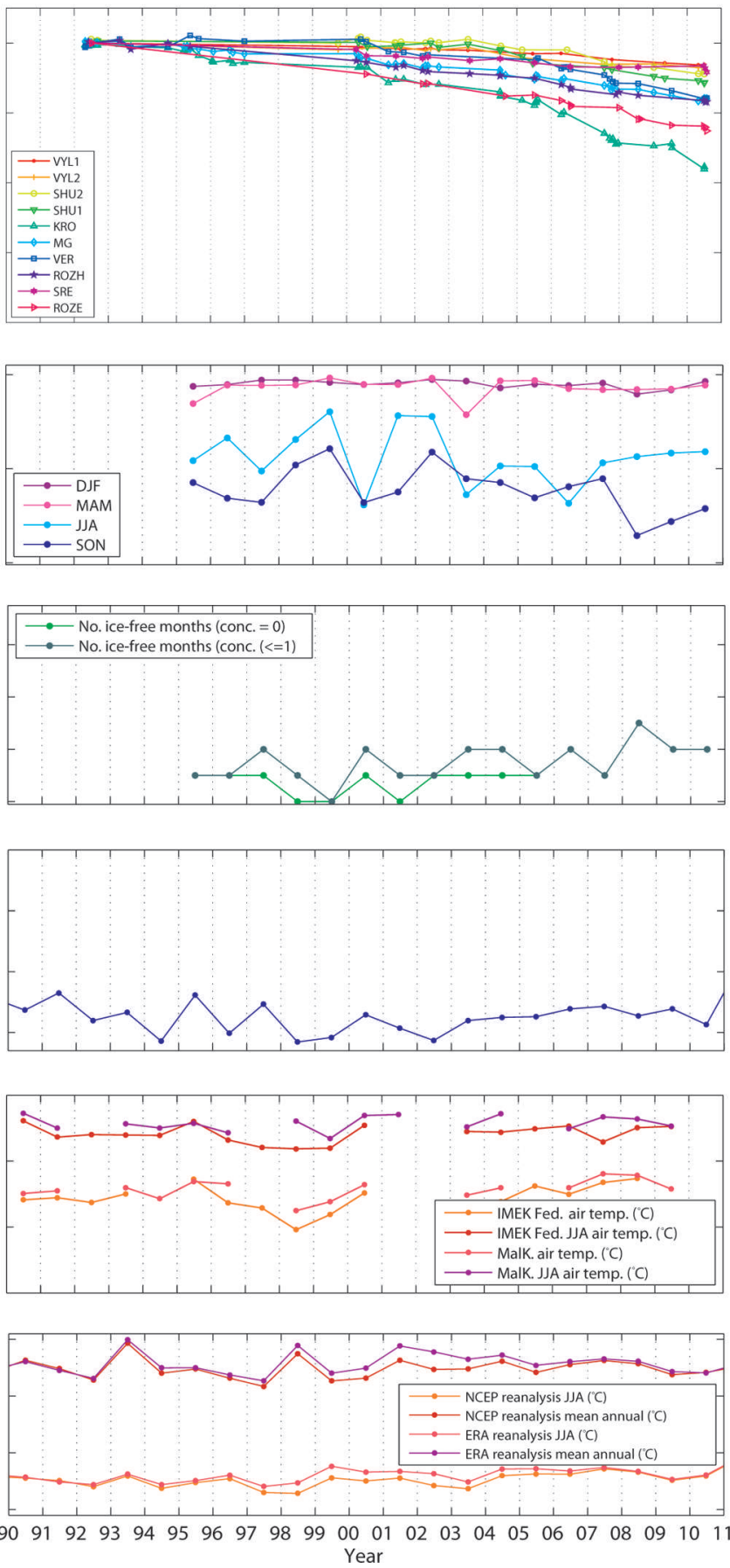

Fig. 6. Relative glacier frontal position and atmospheric/oceanic forcing factors for the Barents Sea coast (left-hand column) and Kara Sea coast (right-hand column). (a) Frontal position for all glaciers, relative to July/August 1992, colour-coded according to glacier and ordered south to north. (b) Mean seasonal sea-ice concentrations for the periods December-February (DJF), March-May (MAM), June-August (JJA) and September-November (SON). (c) Number of months of ice-free conditions. (d) Mean SSTs for July-September (JAS). (e) Mean annual and mean summer (JJA) air temperatures from Malye Karmakuly and Im. E.K. Fedorova meteorological stations (location shown in Fig. 1a). (f) Mean annual and mean summer (JJA) air temperatures from NCEP/NCAR and ERA-Interim reanalysis data at 700 hPa geopotential height.

with interannual retreat rates on certain study glaciers, but were significantly less on rapidly retreating outlets such as VIS. Intra-annual changes in the frontal position on landterminating outlets were indistinguishable from the errors in frontal position.

In addition to spatial variations, the temporal pattern of retreat also differed according to terminus type and coast. Comparison of retreat rates for three time periods (19922000, 2000-05 and 2005-10) showed little change on land-terminating glaciers, whereas retreat rates on marineterminating glaciers increased substantially between each interval (Fig. 5). For the period 1992-2000, the difference in retreat rates between the four groups was small (Fig. 5). Subsequently, retreat rates increased substantially on marineterminating outlets and this was particularly marked on the Barents Sea coast, where retreat rates for the period 2000-05 were three times greater than those for 1992-2000 (Fig. 5). Mean retreat rates then increased further by $\sim 30 \mathrm{ma}^{-1}$ on 


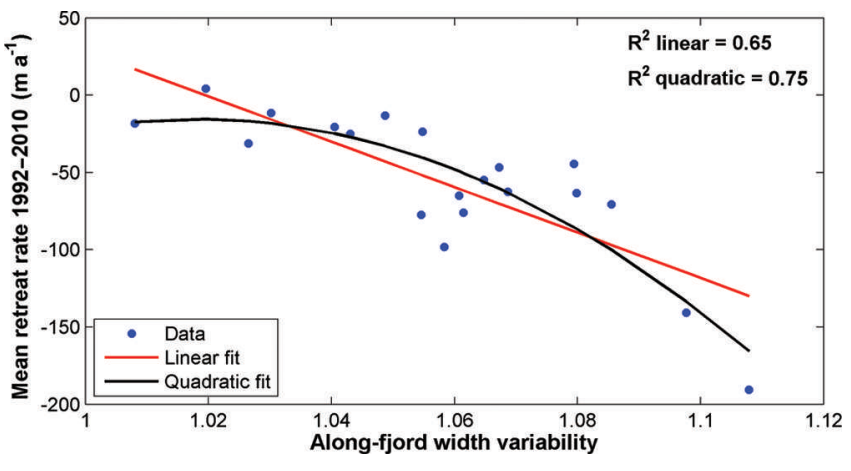

Fig. 7. Scatter plot of along-fjord width variability versus mean rate of frontal position change between 1992 and 2010. This shows the relationship between outlet glacier retreat rate, for all study glaciers with continuous fjord walls, and width variability between the least and most advanced position reached by the glacier terminus during the study period. A value of 1 indicates a straight fjord wall, with increasing values related to increasing variability. Linear (black line) and quadratic (red line) fits were applied to the data.

both coasts between 2000-05 and 2005-10, to reach values of 106.5 and $70.2 \mathrm{~m} \mathrm{a}^{-1}$ on the Barents and Kara Sea coasts, respectively (Fig. 5). In addition to the increase in mean values on marine-terminating glaciers, the range of retreat rates also increased markedly between each time-step. This was particularly notable on the Barents Sea coast, where the range underwent a fivefold increase from $86 \mathrm{~m} \mathrm{a}^{-1}$ in 19922000 to $424 \mathrm{~m} \mathrm{a}^{-1}$ in 2005-10. On the Kara Sea coast, the range increased by almost a factor of three, from $57.8 \mathrm{~m} \mathrm{a}^{-1}$ in 1992-2000 to $166.7 \mathrm{~m} \mathrm{a}^{-1}$ in 2005-10 (Fig. 5).

Regression analysis was used to further assess differences in retreat rates according to terminus type and coast. The first regression model was used to compare the curve for the land-Kara group with the three other groups for each component of the regression equation $\left(B_{0}, B_{1}\right.$ and $\left.B_{2}\right)$ (Fig. 4; Table 1). Results demonstrated no significant difference between the curves for the two land groups. In contrast, the curves for the two groups of marine-terminating glaciers (marine-Barents and marine-Kara) were statistically different from the curve for land-Kara for all components of the regression equation (Fig. 4; Table 1). Taken together this indicates that: (1) retreat rates on land-terminating glaciers on the Barents and Kara Sea coasts were not significantly different from each other; and (2) retreat rates on marineterminating glaciers on both the Barents and Kara Sea coasts were statistically different from retreat rates on landterminating glaciers on both coasts.

The first regression model demonstrated that there was no significant difference between land-terminating glaciers located on different coasts (Table 1). We therefore used a second model to assess the coastal difference in retreat rates for marine-terminating outlets only (Table 2 ). Results show a significant difference in terms of the intercept $\left(B_{0}\right)$, but not in terms of the slope $\left(B_{1}\right)$ or the curvature $\left(B_{2}\right)$ (Table 2$)$. This indicates that the magnitude of retreat on marine-terminating outlets was significantly different between the coasts, but that the rate $\left(B_{1}\right)$ and acceleration $\left(B_{2}\right)$ were not significantly different (Table 2; Fig. 4).

\subsection{Atmospheric and oceanic forcing}

On the Barents Sea coast, sea-ice concentrations during all seasons were high between 1997 and 1999 (Fig. 6b). Sea-ice concentrations decreased markedly in 2000 and 2001
(Fig. 6b) and the mean duration of ice-free conditions increased to 5 months (Fig. 6c). Summer and autumn sea-ice concentrations were relatively high between 2002 and 2004 (Fig. 6b), and the number of ice-free months reduced to 2 (Fig. 6c). From 2005 onwards, sea-ice concentrations were generally very low $(<5 \%)$ during summer and autumn (Fig. 6b), which resulted in ice-free conditions persisting for $\sim 6$ months of the year (Fig. 6c). Winter and spring seaice values also declined markedly between 2004 and 2008 (Fig. 6b).

On the Kara Sea coast, winter and spring sea-ice concentrations remained close to $100 \%$ throughout the study period (Fig. 6b). Summer and autumn concentrations increased between 1997 and 1999, followed by a rapid decrease in 2000 (Fig. 6b) and an increase in the number of ice-free months (Fig. 6c). Sea-ice concentrations remained high during the summers of 2001 and 2002, before decreasing markedly in 2003 and remaining at $~ 50 \%$ thereafter (Fig. 6b). From 2003 onwards, the average number of ice-free months was 2 and reached a peak of 3 in 2008 (Fig. 6c) when autumn sea-ice concentrations also decreased significantly (Fig. 6b).

SSTs in the Barents Sea peaked in 1991 and 1995, followed by a comparatively cool period between 1997 and 1999 (Fig. 6d). SSTs increased again by 2000, decreased substantially in 2003 and increased again by 2004 . Temperatures then increased gradually until 2007 and decreased slowly thereafter. On the Kara Sea coast, SSTs varied considerably between 1990 and 1998, with peaks occurring in 1991, 1995 and 1997 (Fig. 6d). Temperatures were comparatively high in 2000 and then decreased until 2002. Thereafter, SSTs increased gradually until 2007 and decreased slightly in 2008 and 2010 (Fig. 6d). SSTs generally varied in a similar pattern to summer and autumn sea-ice concentrations (Fig. 6)

Air temperatures showed no statistically significant interannual trend at Malye Karmakuly and Im. E.K. Fedorova or in the reanalysis data (Fig. 6e and f). Furthermore, no trend was apparent in summer (June-August) mean values in any of the datasets. Using both reanalysis datasets, a paired $t$ test was used to evaluate whether there was a significant difference in mean annual air temperature before and after the onset of retreat on the Barents Sea coast in 2000 and on the Kara Sea coast in 2003 (Fig. 6e and f). Results demonstrate that there was no significant difference in mean annual air temperature for either period.

\subsection{Catchment area and fjord width variation}

We found no correlation between outlet glacier retreat rate and catchment area $\left(R^{2}=0.08\right)$. The relationship between fjord width variation and glacier retreat was assessed by comparing the value for fjord width variability (Section 2.3) with total retreat rate (1992-2010) for all marine-terminating glaciers with continuous fjord walls $(n=20)$ (Fig. 7). First, we calculated the Pearson's correlation coefficient between width variability and total retreat rate. This gave a value of $r=0.80$ at a confidence level of $>0.01$ (99\%) and demonstrates a strong positive correlation between the two variables. Simple linear regression of width variability versus total retreat rate gave an $R^{2}$ value of 0.65 , and polynomial regression, using a quadratic curve, resulted in an $R^{2}$ value of 0.75 (Fig. 7). Together these results show a statistical relationship between fjord width variability and glacier retreat rates within the study region. 


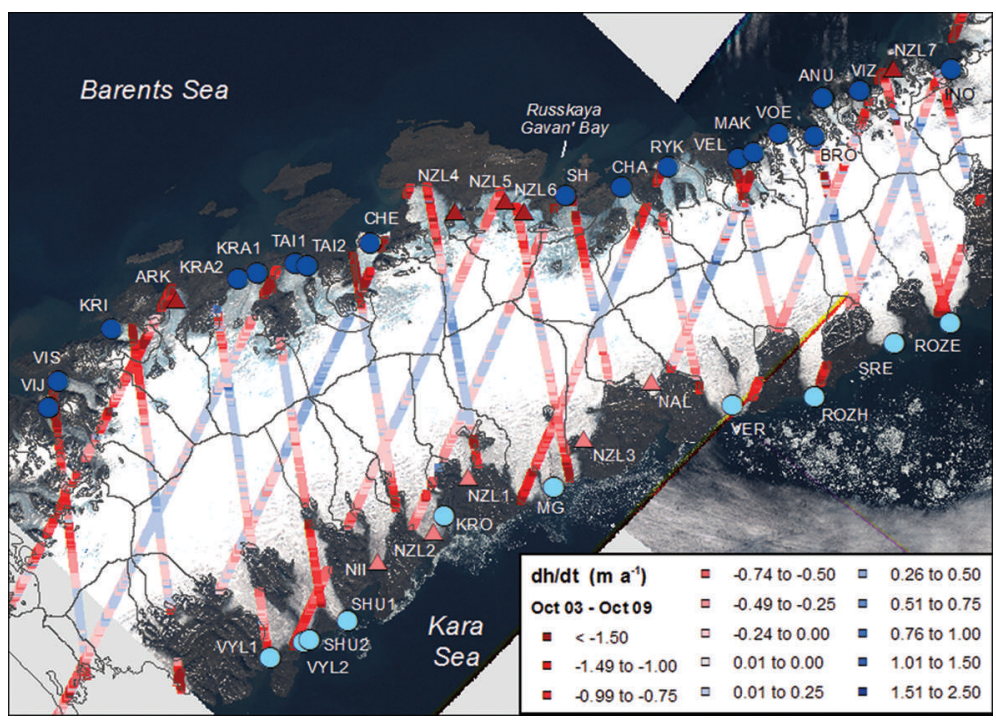

Fig. 8. Rate of elevation change along ICESat laser altimetry tracks for the period October 2003-October 2009. Data provided by G. Moholdt (Moholdt and others, 2012). Study glaciers are symbolized according to coast and terminus type as follows: Barents Sea marineterminating (dark blue circles), Kara Sea marine-terminating (light blue circles), Barents Sea land-terminating (dark red triangles) and Kara Sea land-terminating (light red triangles).

\section{DISCUSSION}

\subsection{Glacier retreat}

Our data demonstrate that the vast majority (90\%) of outlet glaciers on NVZ retreated between 1992 and 2010 (Figs 2 and 5). This concurs with the substantial mass deficit recently reported by Moholdt and others (2012) and highlights the potential contribution of glacier retreat to mass loss from NVZ. The vast majority of retreat occurred on marineterminating outlets, and losses increased over time (Figs 4 and 5), in contrast to land-terminating glaciers where retreat rates were comparable with frontal position errors. The order-of-magnitude difference in retreat rates between marine- and land-terminating outlets is consistent with previous results from the GrIS (Moon and Joughin, 2008; Sole and others, 2008; Pritchard and others, 2009) and Austfonna ice cap, Svalbard (Dowdeswell and others, 2008). However, it contrasts with the pattern of surface elevation change recently reported for NVZ using ICESat laser altimetry data (Fig. 8), which found no significant difference in frontal thinning rates between marine- and land-terminating glaciers (Moholdt and others, 2012). This difference may reflect (1) the spatial coverage of the surface elevation data and/or (2) a delay between terminus retreat and dynamic thinning on marine-terminating outlets. The location of the ICESat tracks results in comparatively sparse data coverage close to the termini of marine-terminating outlets (Fig. 8) where we would expect dynamic thinning in response to recent frontal retreat to be greatest. Consequently, the data may not fully account for near-terminus thinning and may thus underestimate thinning rates on marine-terminating outlets. Alternatively, recent glacier retreat may not yet have initiated dynamic thinning on marine-terminating glaciers, potentially due to slower glacier response times on NVZ in comparison with areas such as the GrIS. If so, recent retreat may result in substantial near-future mass loss from NVZ once the dynamic response begins. This longer-term dynamic component has been highlighted as a potential primary source of future mass loss from the GrIS, where it may account for $>75 \%$ of 21 st-century losses (Price and others, 2011), although dynamic changes may be self-limiting on 200 year timescales (Goelzer and others, 2013). Our data therefore suggest that we may be underestimating the contribution of ice dynamics to recent and/or near-future mass losses on NVZ.

\subsection{Glacier response to atmospheric and oceanic forcing}

\subsubsection{Sea-ice controls}

The marked difference in retreat rates between land- and marine-terminating glaciers suggests that factors operating at the calving front are the primary control on glacier retreat rates on NVZ. Our data show a close correspondence between NVZ glacier frontal position, sea-ice concentrations and the number of ice-free months (Fig. 6). On the Barents Sea coast, outlet glaciers advanced from 1997 until 2000, when sea-ice concentrations were high during all seasons in comparison with the rest of the study period, and the number of ice-free months was small (Fig. 6). Subsequent retreat between 2000 and 2002 was coincident with sea-ice decline, and retreat slowed once again between 2002 and 2004, when sea-ice concentrations increased, particularly during the summer (June-August) (Fig. 6). The main period of retreat occurred between 2004 and 2008, when fjords were largely ice-free in summer and autumn (September-November), and sea-ice concentrations in winter (December-February) and spring (March-May) also declined markedly. Thereafter, retreat rates reduced from 2008, concurrent with an upward trend in winter and spring sea-ice concentrations. A similar correspondence between sea-ice concentrations and frontal position is apparent on the Kara Sea coast, where a brief reduction in sea-ice concentrations in 2000 was coincident with the first phase of marked glacier retreat (Fig. 6). In 2001 and 2002, summer sea-ice concentrations increased markedly and the glaciers underwent limited retreat or even advance. The main retreat phase from 2003 onwards began with a substantial reduction in summer and autumn sea-ice concentrations and was concurrent with an increase in the number of icefree months (Fig. 6). 
Sea-ice concentrations have been identified as a key control on outlet glacier retreat rates in Greenland (Joughin and others, 2008; Amundson and others, 2010; Howat and others, 2010; Carr and others, 2013a,b) and Antarctica (Miles and others, 2013) via their control on calving rates. Formation of winter sea ice is thought to suppress calving by up to a factor of six, whereas seasonal disintegration allows high summer calving rates to commence (Sohn and others, 1998; Joughin and others, 2008; Amundson and others, 2010). Consequently, we suggest that years characterized by late formation and/or early disintegration of sea ice, resulting in a longer seasonal duration of ice-free conditions, promoted higher summer calving rates and net retreat on NVZ. Conversely, years of higher sea-ice concentrations and/or shorter duration of open-water conditions will reduce calving rates, thus lowering retreat rates. On this basis, we suggest sea-ice concentrations are an important control on outlet glacier retreat rates on NVZ. Furthermore, sea-ice conditions may partly account for the difference in retreat rates between the two coasts: on the Barents Sea coast, fjords become seasonally ice-free for up to 6 months of the year, in comparison with a maximum of 3 months of the year on the Kara Sea (Fig. 6). Consequently, higher summer calving rates can persist for longer on the Barents Sea coast and could therefore produce higher mean retreat rates.

\subsubsection{Ocean temperatures}

Changes in SSTs corresponded both with variations in seaice concentrations and the number of ice-free months (Fig. 6). This was particularly marked on the Barents Sea coast, where comparatively low SSTs in 1998-99 and 2003 were concurrent with increased sea-ice concentrations during all months. Conversely, periods of higher SSTs were characterized by lower sea-ice concentrations, as observed in 2000 and 2004 (Fig. 6). This indicates a relationship between SSTs and sea-ice concentrations: higher SSTs may cause sea-ice melt, and lower sea-ice concentrations may promote higher SSTs. Together these factors may facilitate retreat, along with reduced sea-ice concentrations (Joughin and others, 2008; Amundson and others, 2010) and/or undercutting at the waterline due to increased SSTs (Vieli and others, 2002; Benn and others, 2007), which may increase calving rates. Thus, periods of higher SSTs are likely to promote glacier retreat on NVZ. Previous studies have documented mass gains on NVZ during periods of higher Barents SSTs due to increased accumulation, which has been linked to positive phases of the North Atlantic Oscillation (NAO) and increased winter precipitation (Zeeberg and Forman, 2001). However, our data suggest that higher SSTs may also promote retreat, which may partly offset the surface mass-balance gains during positive phases of the NAO.

In addition to surface changes, higher SSTs during positive phases of the NAO are thought to reflect the increased advection of warm Atlantic water (AW) into the Barents Sea (Loeng, 1991; Hurrell, 1995). This has important implications for submarine melt rates and glacier behaviour on NVZ: SSTs are unlikely to cause significant mass loss through glacial melt, whereas warming at depth can result in rapid submarine melting (Motyka and others, 2003, 2011; Rignot and others, 2010). As outlined above, oceanic warming may also cause retreat via waterline melting and undercutting of the terminus (Vieli and others, 2002; Benn and others, 2007). Topographic maps indicate that fjord depths around NVZ are of the order of 100-200 m deep near the glacier termini, meaning that they are considerably shallower than major outlet glacier fjords in Greenland and likely to only be close to flotation at the calving front. Furthermore, calving generally occurs via small icebergs $(<200 \mathrm{~m})$, rather than large tabular icebergs, further indicating that the glaciers do not have extensive floating sections. As a consequence of the limited floating sections and comparatively shallow grounding-line depths, the relative contribution of undercutting at the waterline to oceaninduced mass loss may be more significant on NVZ than in areas with deeper fjords, such as the GrlS.

Previous studies have highlighted the distribution and properties of AW as a potentially key control on Greenland glacier dynamics and have demonstrated that it can penetrate to the calving front (Holland and others, 2008; Murray and others, 2010; Christoffersen and others, 2011; Straneo and others, 2011; Andresen and others, 2012). On the Barents Sea coast, modified AW is present on the Novaya Zemlya Bank (Fig. 1), within the West Novaya Zemlya Current (Pfirman and others, 1994; Ivanov and Shapiro, 2005; Arthun and others, 2011), and the glacier fjords of our study are comparatively short and open to the ocean (Fig. 2). Very few direct measurements of oceanographic conditions are available from NVZ glacier fjords, meaning that little is known about fjord circulation and/or the potential for the offshore AW to reach the glacier termini. However, subsurface ocean temperatures have been measured in Russkaya Gavan' Bay (Fig. 2), at points located 3.5 and $9.6 \mathrm{~km}$ from the terminus of Shokalskogo glacier $(\mathrm{SH})$ (Politova and others, 2012). Water temperatures of almost $3.5^{\circ} \mathrm{C}$ were recorded between depths of 30 and $65 \mathrm{~m}$, providing empirical evidence that warm water can access at least some Barents Sea fjords. These temperatures are higher than those recorded at the same depth in the fjords of Helheim, Kangerdlugssuaq and Jakobshavn Isbræ, Greenland, and are comparable with values recorded in deeper water masses $(>200 \mathrm{~m})$ within these fjords, which are thought to be of Atlantic origin (Holland and others, 2008; Straneo and others, 2010; Christoffersen and others, 2011).

In the Kara Sea, Atlantic-derived water masses enter at three points: via the Kara Strait in the south, via the passage between Franz Josef Land and NVZ, and through the St Anna Trough in the north (Fig. 1) (Pavlov and Pfirman, 1995; Karcher and others, 2003). Near the Kara Strait, surface ocean temperatures of up to $9^{\circ} \mathrm{C}$ have been recorded during late summer, with warming thought to extend to depths of up to $60 \mathrm{~m}$ (Pavlov and Pfirman, 1995). In the northern Kara Sea, water temperatures of $\sim 1.5^{\circ} \mathrm{C}$ have been measured at the St Anna Canyon (depth $\sim 300 \mathrm{~m}$ ) (Hanzlick and Aagaard, 1980) and offshore of the northern tip of NVZ (depth $\sim 125 \mathrm{~m}$ ) (Karcher and others, 2003). The latter area is characterized by late freezing and thin sea ice, in comparison with the rest of the Kara Sea, and previous studies have highlighted the potential link between AW and sea-ice conditions in the region (Hanzlick and Aagaard, 1980). This evidence suggests that Atlantic-derived water has the potential to influence glacier behaviour on the Kara Sea coast, via submarine melting and/or sea-ice controls, and that differences in oceanographic conditions may contribute to the coastal difference in glacier retreat rates. However, detailed oceanographic measurements are required on both coasts to assess the extent to which oceanic changes are transmitted to the glacier front and their influence on glacier 
behaviour. We therefore highlight this as an important area for future research, given the rapid recent retreat of marineterminating outlets on NVZ, their apparent sensitivity to changes at the ocean boundary and the potential for rapid connections between the glacier termini and warm continental shelf waters.

\subsubsection{Atmospheric forcing}

Previous studies have identified a number of different mechanisms by which air temperatures may drive marineterminating outlet glacier retreat: (1) hydrofracture of crevasses at the terminus/lateral margins (Sohn and others, 1998; Andersen and others, 2010; Vieli and Nick, 2011); (2) sea-ice melting; and/or (3) enhanced submarine melting due to subglacial meltwater plumes (Sohn and others, 1998; Motyka and others, 2003, 2011). From visual inspection of satellite imagery, we see no evidence of significant areas of water-filled crevasses during the melt season, and calving generally occurs via small icebergs $(<200 \mathrm{~m})$ rather than large tabular icebergs. This indicates that the glacier termini do not have extensive floating sections and will therefore be less vulnerable to full-thickness fracture via meltwaterenhanced crevassing. Moreover, our data show no clear correspondence between variations in air temperature and sea ice (Fig. 6). Instead, sea-ice variability corresponded with changes in SSTs, suggesting that they may be a more significant influence on sea-ice concentrations than air temperatures. Meltwater plumes have been highlighted as a potentially important control on outlet glacier behaviour elsewhere in the Arctic (Motyka and others, 2003, 2011; Christoffersen and others, 2011; Seale and others, 2011; Straneo and others, 2011), and turbid meltwater plumes are evident at the glacier termini. However, very limited oceanographic data are available from NVZ glacial fjords, which precludes a detailed assessment of this mechanism.

Our results show limited correspondence between air temperatures and frontal position variations on NVZ. During the study period, no statistically significant trend was evident in any of our air temperature datasets, in contrast to the acceleration in marine-terminating glacier retreat, and we find no statistical difference in air temperatures before and after the onset of retreat on either coast (Figs 4 and 6). Although previous findings from the GrlS suggest that the response of marine-terminating glaciers to forcing at the terminus is rapid (Vieli and Nick, 2011), we also calculated air temperature trends from the 1950s to the present using reanalysis data, in order to identify any longer-term forcing to which glacier dynamics might be responding. During this time period, we found no significant trend in mean annual or mean summer (June-August) air temperatures in any of the datasets, and mean annual values showed marked interannual and interdecadal variability. Although comparison of meteorological station data with retreat rates is limited by data availability, the pattern of retreat on the Kara Sea coast showed little correspondence to air temperature variations at either meteorological station (Fig. 6). On the Barents Sea coast, the onset of retreat in 2000 followed 2 years of atmospheric warming, but temperatures were equally warm at other points during the study period when retreat rates were lower (Fig. 5). Previous studies have suggested that a longitudinal temperature gradient exists across NVZ (Zeeberg and Forman, 2001), which could potentially contribute to the difference in retreat rates between the Barents and Kara Sea coasts This potential
Table 3. Theoretical influence of widening/narrowing of a fjord in the along-flow direction on outlet glacier dynamics

\begin{tabular}{lll}
\hline & Widening & Narrowing \\
\hline Surface slope & Decreases & Increases \\
Ice thickness & Decreases & Increases \\
Lateral stress and resistance to flow & Decreases & Increases \\
Vulnerability to fracture & Increases & Decreases \\
Calving rate & Increases & Decreases \\
Velocity & Increases & Decreases \\
Retreat rate & Increases & Decreases \\
& & \\
\hline
\end{tabular}

coastal difference cannot be assessed because of lack of data. However, our results provide no evidence for a change in air temperatures that coincided with glacier retreat, suggesting that they are not a primary driver of marineterminating glacier retreat on NVZ.

\subsection{Fjord width variation}

Although mean retreat rates were somewhat higher on the Barents Sea coast than on the Kara Sea coast (Figs 4 and 5), there were large variations in retreat rates between glaciers located on the same coast and even between neighbouring glaciers (Figs 2 and 4), despite being subject to comparable forcing. Together, this evidence suggests that factors specific to each glacier can modulate the glacier's response to forcing. A number of potential glacier-specific controls have been identified to date, including catchment area, glacier width and basal topography (Carr and others, 2013a). We found no correlation between outlet glacier retreat rate and catchment area $\left(R^{2}=0.08\right)$. However, our data suggest that along-flow variations in fjord width are an important control, and we demonstrate a statistical relationship between fjord width variability and glacier retreat across the study region. We suggest that along-flow width variations may influence retreat rates via two mechanisms: (1) owing to the principle of mass conservation, widening of the fjord would mean that the glacier needs to thin and the surface slope needs to reduce in order to maintain the same ice flux, which would make the ice more vulnerable to thinning and eventually to flotation, thus increasing calving rates and promoting retreat $\left(\mathrm{O}^{\prime} \mathrm{Neel}\right.$ and others, 2005); and (2) lateral resistive stresses tend to decrease with increasing width, which would reduce resistance to flow and promote further dynamics thinning and retreat (Raymond, 1996).

In addition to the relationship between retreat rates and width variability, we assessed the relative importance of specific types of width variation (Fig. 3). Based on the hypothesis outlined above, widening of the fjord in the along-flow direction, either rapidly (class I) or gradually (class II), is likely to promote retreat and acceleration (Table 3). Conversely, narrowing of the fjord, either at pinning points (class III) or progressively (class IV), would be expected to reduce retreat rates and ice velocities (Table 3). These changes are likely to occur more rapidly where pinning points are present (classes I and IV) than where changes in fjord width are gradual (classes II and III). Glaciers undergoing minimal along-flow width variation (class VI) will experience limited changes in surface slope, thickness and/or resistive stresses over time, meaning that these factors will have a minimal effect on glacier retreat rates and/or ice velocities. 

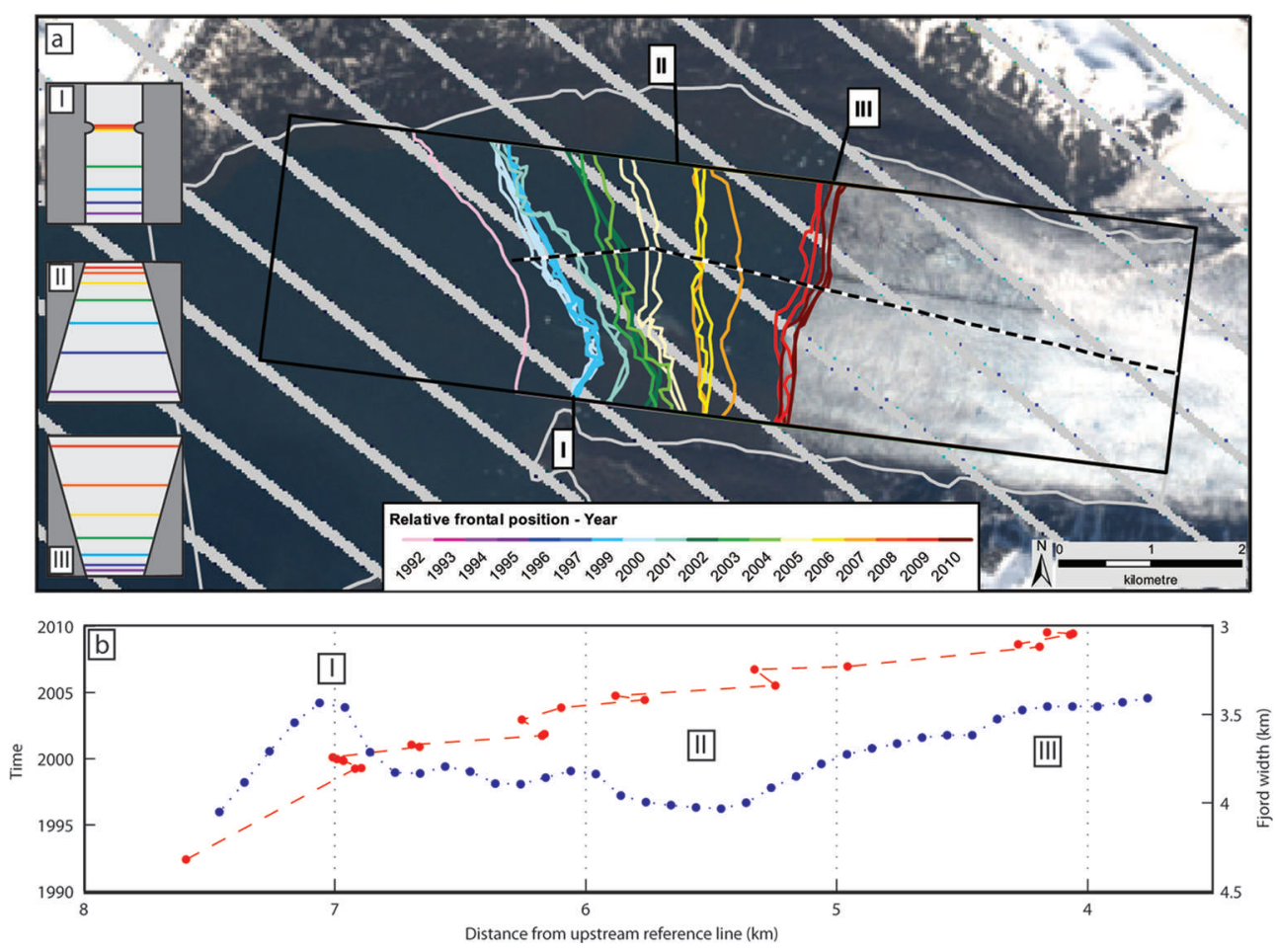

Fig. 9. Frontal position of Vil'kitskogo Sev. (VIS) in relation to fjord width perpendicular to the glacier centre line. (a) VIS frontal position over time (colour-coded by year), glacier centre line (black dashed line) and fjord margins as sea level (light grey line). Base image: Landsat scene acquired on 7 July 2010, provided by the USGS Global Visualization Viewer. (b) Fjord width perpendicular to the centre line (blue), in relation to glacier frontal position (red).

Our results demonstrate that rapid retreat was associated with widening fjords and was particularly marked where glaciers retreated from pinning points (Fig. 3). This was exemplified by VIS, located on the Barents Sea coast (Fig. 2), which exhibited the highest mean retreat rate between 1992 and 2010 and the fjord width of which varied by $16 \%$ between the most and the least extended frontal positions. Between January 1996 and August 2001, the glacier front occupied a very similar position at a comparatively narrow point of the fjord and its southern margin was attached to a prominent pinning point (Fig. 9, point I). The glacier then retreated rapidly from April 2002, as the southern margin retreated from the pinning point and the front moved into a wider section of the fjord (Fig. 9, point II). Retreat persisted until May 2009, when the fjord narrowed (Fig. 9, point III). This relationship between frontal retreat, pinning points and variations in fjord width is consistent with previous empirical results from Greenland (Warren and Glasser, 1992; Carr and others, 2013b) and numerical modelling studies (Jamieson and others, 2012).

Our results also demonstrate that the glaciers exhibiting the lowest retreat rates have a relatively uniform width along their retreat path and their termini were generally located at narrow points within the fjord (Fig. 3). This is illustrated by Brounova (BRO), which underwent the smallest retreat during the study period. The fjord width varied very little $(2.5 \%)$ between the minimum and maximum frontal positions, and the terminus occupied a comparatively narrow section of fjord throughout this period (Fig. 10). However, the fjord widens upstream of the current terminus position (Fig. 10), which may facilitate retreat in the future if forcing is sufficient to move the front into this wider section. BRO is located on the Barents Sea coast $\sim 195 \mathrm{~km}$ north of VIS. Despite this latitudinal difference, sea-ice concentrations at these two glaciers varied by only $4 \%$, whereas the absolute change in frontal position was 48 times greater on VIS than $\mathrm{BRO}$, with VIS retreating by $190 \mathrm{~m} \mathrm{a}^{-1}$ and BRO advancing by $4 \mathrm{~m} \mathrm{a}^{-1}$ during the study period (Fig. 3). A similar pattern is evident along the Barents Sea coast, where the variation in mean monthly sea-ice concentrations was small $(\mathrm{SD}=$ $0.67 \%)$, but total retreat rate varied markedly, ranging between +4 and $-190 \mathrm{~m} \mathrm{a}^{-1}\left(\mathrm{SD}=47.35 \mathrm{~m} \mathrm{a}^{-1}\right)$ (Figs 3 and 5). On the Kara Sea coast, total retreat rates also showed substantial variation $\left(\mathrm{SD}=25.75 \mathrm{~m} \mathrm{a}^{-1}\right)$ and variability in seaice concentrations was limited, although slightly higher than on the Barents Sea coast $(\mathrm{SD}=2.34 \%)$. Thus, evidence indicates that there is high variation in retreat rates on both coasts between individual glaciers, but limited variation in forcing, and we suggest that variations in fjord width contribute substantially to these differences.

In addition to the two extreme cases described above, a number of study glaciers experienced retreat only at the central portion of the terminus, while the margins remained on lateral pinning points (Fig. 3). This occurred mainly on the relatively wide outlet glaciers located on the Kara Sea coast, from Moshnyij (MG) northwards (Fig. 2), and is exemplified by the pattern of retreat on MG (Fig. 11). Although detailed bathymetric data are unavailable, topographic maps indicate that the area immediately offshore of these glaciers is shallow and gently sloping, and previous studies suggest that glaciers on the Kara Sea coast terminate in shallow water (Kotlyakov, 2006). Owing to the comparatively shallow and wide fjords, ice close to the lateral margins is more likely to be grounded and retreat may therefore be limited to the central portion, where water depths are sufficient to bring the termini close to flotation. Consequently, contemporary forcing may be insufficient to dislodge the glacier termini from their lateral pinning points. 

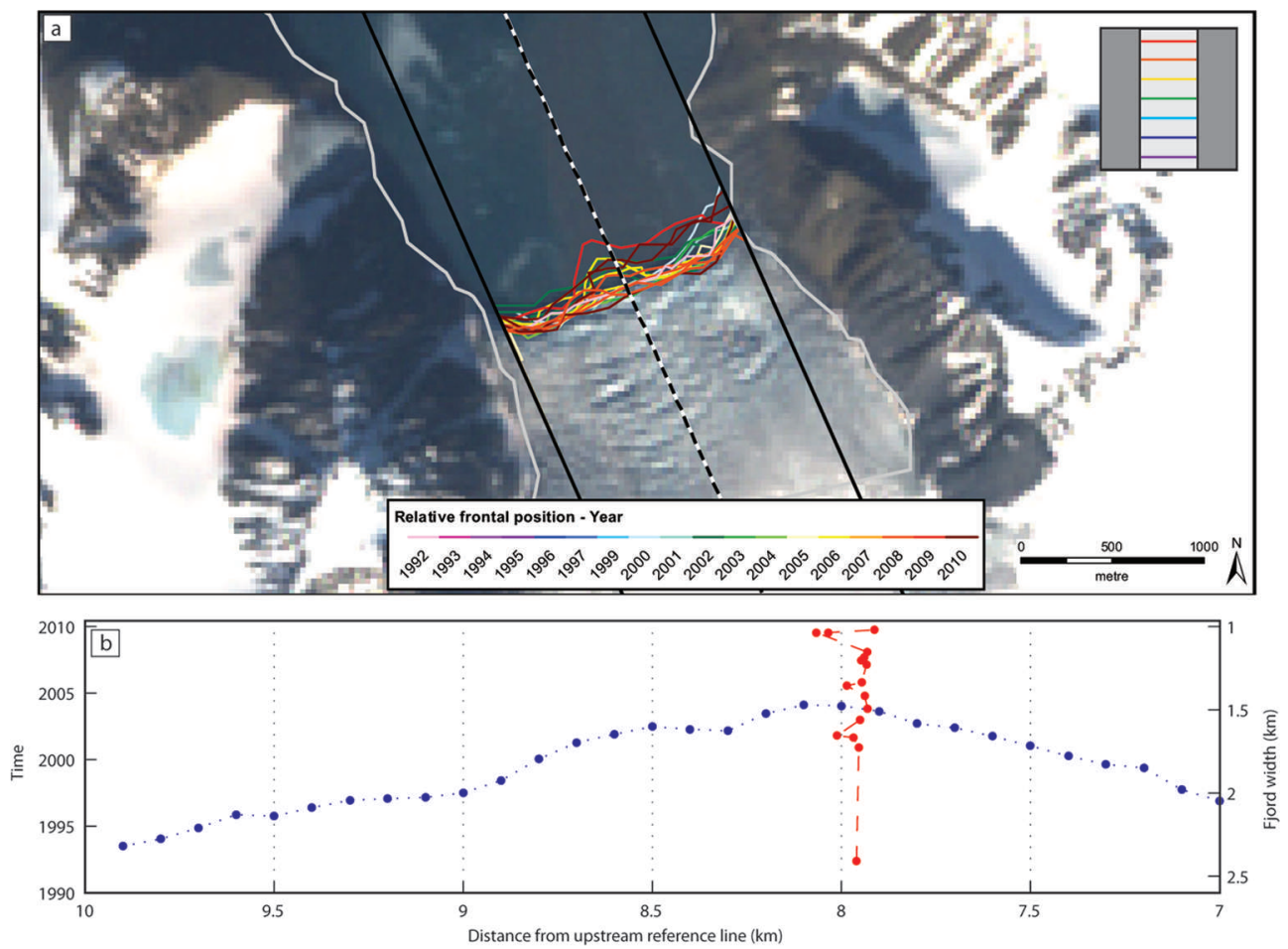

Fig. 10. Frontal position of Brounova $(B R O)$ in relation to fjord width perpendicular to the glacier centre line. (a) BRO frontal position over time (colour-coded by year), glacier centre line (black dashed line) and fjord margins as sea level (light grey line). Base image: Landsat scene acquired on 13 August 2011, provided by the USGS Global Visualization Viewer. (b) Fjord width perpendicular to the centre line (blue), in relation to glacier frontal position (red).

This contrasts with fjords located on the Barents Sea coast and further south on the Kara Sea, which are narrower and possibly deeper, as indicated by previous results (Kotlyakov, 2006) and bathymetric data from the topographic maps. Narrower fjords are likely to result in a greater contribution of lateral stresses to the force budget, and deeper fjords may allow the terminus to reach near-flotation, which could then facilitate rapid retreat via a series of positive feedbacks once the terminus has moved beyond a pinning point. As a result, differences in fjord geometry may also contribute to the coastal difference in mean retreat rates, as the majority of the wide, shallow fjords are located on the northern Kara Sea coast. A number of the marine-terminating study glaciers also have a portion of their ice front that is landterminating and this is particularly notable within the northern section of the Kara Sea (Fig. 3). However, this

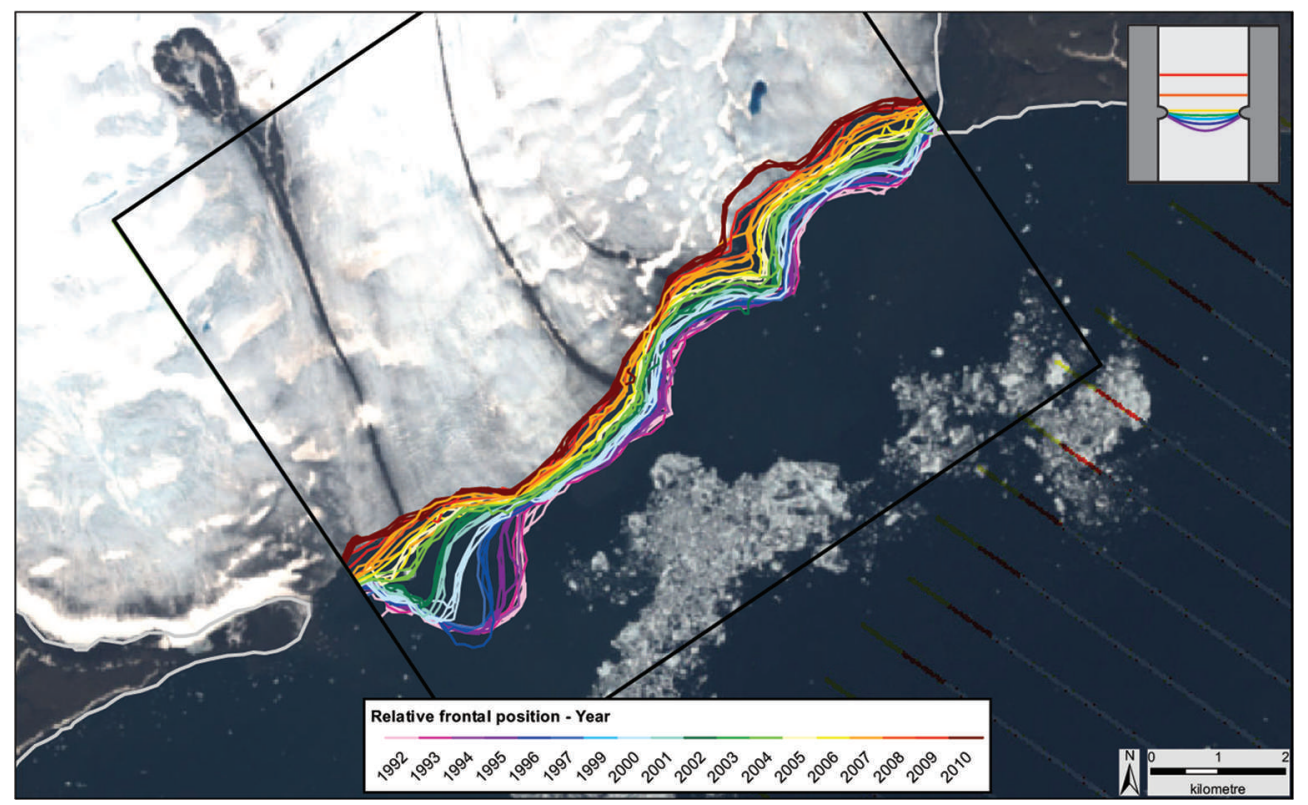

Fig. 11. Frontal position of Moshny (MG) in relation to fjord width perpendicular to the glacier centre line. MG frontal position over time (colour-coded by year), glacier centre line (black dashed line) and fjord margins as sea level (light grey line). Base image: Landsat scene acquired on 13 August 2011, provided by the USGS Global Visualization Viewer. 
characteristic appears to bear little relationship to glacier retreat rate during the study period (Fig. 3).

At present, no data are available on the subglacial topography of NVZ outlet glaciers, and bathymetric information within the fjords is limited. Our results suggest that fjord bathymetry may influence the pattern and magnitude of glacier retreat on the northern section of the Kara Sea coast, where fjords may be comparatively shallow. Retreat rates vary spatially along the fronts of these glaciers (Fig. 11), which may reflect local variations in basal topography and/or bathymetry. Furthermore, rock islands are visible at the calving of a number of the study glaciers (e.g. Krivosheina $(\mathrm{KRI})$ and Chernysheva $(\mathrm{CHE})$ ), which may promote retreat as the terminus recedes and ungrounds from these pinning points. It has been suggested that loss of contact with basal pinning points contributed to the dramatic retreat of Jakobshavn Isbræ, West Greenland (Thomas and others, 2003). Basal topography has been identified as a potentially important control on outlet glacier dynamics in other Arctic regions (Meier and Post, 1987; Nick and others, 2009; Thomas and others, 2009) and our results underscore the influence of fjord geometry on glacier retreat rates. Thus, basal topographic and bathymetric data in NVZ are urgently needed to fully understand the factors controlling outlet glacier behaviour and modulating their response to forcing.

\section{CONCLUSIONS}

Major outlet glaciers on NVZ have retreated rapidly between 2000 and 2010. Retreat rates were an order of magnitude greater on marine-terminating outlets than on land-terminating glaciers. Marine-terminating glacier retreat has accelerated over time, and the temporal pattern of retreat corresponded closely to changes in sea-ice concentration. Retreat rates were significantly higher on the Barents Sea coast than on the Kara Sea coast, most likely because of the differences in sea-ice concentration and duration. Despite a consistent overall retreat trend, however, there was a large range in retreat rates between outlet glaciers located on the same coast, which far exceeded variations in forcing. We identify fjord width variability as a key factor modulating glacier response to forcing and show a significant relationship between this factor and total glacier retreat rates. Using empirical evidence, we categorize the influence of fjord width and highlight lateral pinning points as an important control. We suggest that these qualitative criteria encompass the primary classes of glacier response to fjord width variation and may therefore prove a useful framework for interpreting and assessing observations of marineterminating outlet glacier retreat in other regions. Future work should measure subsurface ocean conditions (temperature and salinity) within outlet glacier fjords, given the apparent sensitivity of NVZ glaciers to changes at the calving front. Information on fjord bathymetry and subglacial topography is also required, as fjord geometry appears to be a key control on NVZ outlet glacier retreat rates, but the influence of basal topography in this region has yet to be quantified. Our data indicate that variations in fjord width can strongly influence the behaviour of a large sample of study glaciers and we highlight the danger of extrapolating retreat rates without due consideration of these local factors. We underscore the need to consider the dynamic component of mass loss from NVZ in order to accurately forecast near-future losses.

\section{ACKNOWLEDGEMENTS}

This work was supported by a Durham Doctoral Scholarship granted to J.R. Carr. Envisat and ERS Image Mode Precision scenes were provided by the European Space Agency. We thank N.J. Cox, G. Moholdt and A. Gardner for helpful comments, and Mauri Pelto and Michael Willis for thoughtful reviews.

\section{REFERENCES}

Amundson JM, Fahnestock M, Truffer M, Brown J, Lüthi MP and Motyka RJ (2010) Ice mélange dynamics and implications for terminus stability, Jakobshavn Isbræ, Greenland. J. Geophys. Res., 115(F1), F01005 (doi: 10.1029/2009JF001405)

Andersen ML and 14 others (2010) Spatial and temporal melt variability at Helheim Glacier, East Greenland, and its effect on ice dynamics. J. Geophys. Res., 115(F4), F04041 (doi: 10.1029/ 2010JF001760)

Andresen CS and 10 others (2012) Rapid response of Helheim Glacier in Greenland to climate variability over the past century. Nature Geosci., 5(1), 37-41 (doi: 10.1038/ngeo1349)

Arendt A and 77 others (2012) Randolph Glacier Inventory (RGI), Vers. 1.0: a dataset of Global Glacier Outlines. Global Land Ice Measurements from Space, Boulder, CO. Digital media: http:// www.glims.org/RGl/randolph.html

Årthun M, Ingvaldsen RB, Smedsrud LH and Schrum C (2011) Dense water formation and circulation in the Barents Sea. DeepSea Res. I, 58(8), 801-817 (doi: 10.1016/j.dsr.2011.06.001)

Bassford RP, Siegert MJ and Dowdeswell JA (2006) Quantifying the mass balance of ice caps on Severnaya Zemlya, Russian High Arctic. III: Sensitivity of ice caps in Severnaya Zemlya to future climate change. Arct. Antarct. Alp. Res., 38(1), 21-33

Benn DI, Warren CW and Mottram RH (2007) Calving processes and the dynamics of calving glaciers. Earth-Sci. Rev., 82(3-4), 143-179 (doi: 10.1016/j.earscirev.2007.02.002)

Burgess D and Sharp MJ (2008) Recent changes in thickness of the Devon Island ice cap, Canada. J. Geophys. Res., 113(B7), B07204 (doi: 10.1029/2007JB005238)

Carr JR, Stokes CR and Vieli A (2013a) Recent progress in understanding marine-terminating Arctic outlet glacier response to climatic and oceanic forcing. Twenty years of rapid change. Progr. Phys. Geogr., 37(4), 436-467 (doi: 10.1177/ 0309133313483163)

Carr JR, Vieli A and Stokes CR (2013b) Climatic, oceanic and topographic controls on marine-terminating outlet glacier behavior in north-west Greenland at seasonal to interannual timescales. J. Geophys. Res., 118(3), 1210-1226 (doi: 10.1002/ jgrf.20088)

Christoffersen P and 7 others (2011) Warming of waters in an East Greenland fjord prior to glacier retreat: mechanisms and connection to large-scale atmospheric conditions. Cryosphere, 5(3), 701-714 (doi: 10.5194/tc-5-701-2011)

Dee DP and 35 others (2011) The ERA-Interim reanalysis: configuration and performance of the data assimilation system. Q. J. R. Meteorol. Soc., 137(656), 553-597 (doi: 10.1002/ qj.828)

Dowdeswell JA and Williams M (1997) Surge-type glaciers in the Russian High Arctic identified from digital satellite imagery. J. Glaciol., 43(145), 489-494

Dowdeswell JA and 10 others (1997) The mass balance of circum-Arctic glaciers and recent climate change. Quat. Res., 48(1), 1-14

Dowdeswell JA, Benham TJ, Strozzi T and Hagen JO (2008) Iceberg calving flux and mass balance of the Austfonna ice cap on Nordaustlandet, Svalbard. J. Geophys. Res., 113(F3), F03022 (doi: 10.1029/2007JF000905)

Enderlin EM and Howat IM (2013) Submarine melt rate estimates for floating termini of Greenland outlet glaciers (2000-2010). J. Glaciol., 59(213), 67-75 (doi: 10.3189/2013JoG12J049) 
Gardner AS and 8 others (2011) Sharply increased mass loss from glaciers and ice caps in the Canadian Arctic Archipelago. Nature, 473(7347), 357-360 (doi: 10.1038/nature10089)

Gardner A, Moholdt G, Arendt A and Wouters B (2012) Accelerated contributions of Canada's Baffin and Bylot Island glaciers to sea level rise over the past half century. Cryosphere, 6(5), 1103-1125 (doi: 10.5194/tc-6-1103-2012)

Gardner AS and 15 others (2013) A reconciled estimate of glacier contributions to sea level rise: 2003 to 2009. Science, 340(6134), 852-857 (doi: 10.1126/science.1234532)

Goelzer H and 8 others (2013) Sensitivity of Greenland ice sheet projections to model formulations. J. Glaciol., 59(216), 733-749 (doi: 10.3189/2013JoG12J182)

Grant KL, Stokes CR and Evans IS (2009) Identification and characteristics of surge-type glaciers on Novaya Zemlya, Russian Arctic. J. Glaciol., 55(194), 960-972 (doi: 10.3189/ 002214309790794940)

Hanzlick D and Aagaard K (1980) Freshwater and Atlantic water in the Kara Sea. J. Geophys. Res., 85(C9), 4937-4942 (doi: 10.1029/JC085iC09p04937)

Holland DM, Thomas RH, De Young B, Ribergaard MH and Lyberth B (2008) Acceleration of Jakobshavn Isbræ triggered by warm subsurface ocean waters. Nature Geosci., 1(10), 659-664 (doi: 10.1038/ngeo316)

Howat IM, Joughin I, Fahnestock $M$, Smith BE and Scambos T (2008) Synchronous retreat and acceleration of southeast Greenland outlet glaciers 2000-2006: ice dynamics and coupling to climate. J. Glaciol., 54(187), 646-660 (doi: 10.3189/ 002214308786570908)

Howat IM, Box JE, Ahn Y, Herrington A and McFadden EM (2010) Seasonal variability in the dynamics of marine-terminating outlet glaciers in Greenland. J. Glaciol., 56(198), 601-613 (doi: 10.3189/002214310793146232)

Hurrell JW (1995) Decadal trends in the North Atlantic Oscillation: regional temperatures and precipitation. Science, 269(5224), 676-679 (doi: 10.1126/science.269.5224.676)

Ivanov VV and Shapiro GI (2005) Formation of a dense water cascade in the marginal ice zone in the Barents Sea. Deep-Sea Res. I, 52(9), 1699-1717 (doi: 10.1016/j.dsr.2005.04.004)

Jamieson SSR and 6 others (2012) Ice-stream stability on a reverse bed slope. Nature Geosci., 5(11), 799-802 (doi: 10.1038/ ngeo1600)

Joughin I and 7 others (2008) Continued evolution of Jakobshavn Isbræ following its rapid speedup. J. Geophys. Res., 113(F4), F04006 (doi: 10.1029/2008JF001023)

Kalnay E and 21 others (1996) The NCEP/NCAR 40-year reanalysis project. Bull. Am. Meteorol. Soc., 77(3), 437-471 (doi: 10.1175/ 1520-0477(1996)077<0437:TNYRP>2.0.CO;2)

Karcher MJ, Kulakov M, Pivovarov S, Schauer U, Kauker F and Schlitzer R (2003) Atlantic water flow to the Kara Sea: comparing model results with observations. In Stein R, Fahl K, Fütterer DK, Galimov EM and Stepanets OV eds. Siberian river run-off in the Kara Sea: characterisation, quantification, variability and environmental significance. (Proceedings in Marine Science 6) Elsevier, Amsterdam, 47-69

Korona J, Berthier E, Bernard M, Rémy F and Thouvenot E (2009) SPIRIT. SPOT 5 stereoscopic survey of polar ice: reference images and topographies during the fourth International Polar Year (2007-2009). ISPRS J. Photogramm. Remote Sens., 64(2), 204-212 (doi: 10.1016/j.isprsjprs.2008.10.005)

Kotlyakov VM ed. (1978) Katalog lednikov SSSR: Tom 3, Severnyj Kraj, Chast' 2 Novaja Zemlja [Catalogue of glaciers of USSR: Volume 3, Northern Area, Part 2, Novaya Zemlya]. Hydrometeoizdat, Leningrad [in Russian]

Kotlyakov VM ed. (2006) Oledenenie Severnoj i Central'noj Evrazii v Sovremennuju epochu [Glaciation in north and central Eurasia at present time]. Nauka, Moscow [in Russian with English summary]

Kotlyakov VM, Glazovsii AF and Frolov IE (2010) Glaciation in the Arctic: causes and effects of global changes. Herald Russ. Acad. Sci., 80(2), 155-164 (doi: 10.1134/S1019331610020073)
Kouraev AV, Legrésy B and Remy F (2006) Northern Novaya Zemlya outlet glaciers: 1990-2000 changes. LEGOS INTEGRAL Team, http://www.legos.obs-mip.fr/pdf/equipe/cryosphere-satellitaire/ projets-spatiaux/northen-novaya-zembya-outlet

Lenaerts JTM, Van Angelen JH, Van den Broeke MR, Gardner AS, Wouters B and Van Meijgaard E (2013) Irreversible mass loss of Canadian Arctic Archipelago glaciers. Geophys. Res. Lett., 40(5), 870-874 (doi: 10.1002/grl.50214)

Loeng H (1991) Features of the physical oceanographic conditions of the Barents Sea. Polar Res., 10(1), 5-18 (doi: 10.1111/j.17518369.1991.tb00630.x)

McFadden EM, Howat IM, Joughin I, Smith BE and Ahn Y (2011) Changes in the dynamics of marine-terminating outlet glaciers in West Greenland (2000-2009). J. Geophys. Res., 116(F2), F02022 (doi: 10.1029/2010JF001757)

Meier MF and Post A (1987) Fast tidewater glaciers. J. Geophys. Res., 92(B9), 9051-9058 (doi: 10.1029/JB092iB09p09051)

Meier MF and 7 others (2007) Glaciers dominate eustatic sea-level rise in the 21st century. Science, 317(5841), 1064-1067 (doi: 10.1126/science.1143906)

Miles BWJ, Stokes CR, Vieli A and Cox NJ (2013) Rapid, climatedriven changes in outlet glaciers on the Pacific coast of East Antarctica. Nature, 500(7464), 563-566 (doi: 10.1038/nature12382)

Moholdt G, Nuth C, Hagen JO and Kohler J (2010) Recent elevation changes of Svalbard glaciers derived from ICESat laser altimetry. Remote Sens. Environ., 114(11), 2756-2767 (doi: 10.1016/ j.rse.2010.06.008)

Moholdt G, Wouters B and Gardner AS (2012) Recent mass changes of glaciers in the Russian High Arctic. Geophys. Res. Lett., 39(10), L10502 (doi: 10.1029/2012GL051466)

Moon T and Joughin I (2008) Changes in ice front position on Greenland's outlet glaciers from 1992 to 2007. J. Geophys. Res., 113(F2), F02022 (doi: 10.1029/2007JF000927)

Moon T, Joughin I, Smith B and Howat I (2012) 21st-century evolution of Greenland outlet glacier velocities. Science, 336(6081), 576-578 (doi: 10.1126/science.1219985)

Motyka RJ, Hunter L, Echelmeyer KA and Connor C (2003) Submarine melting at the terminus of a temperate tidewater glacier, LeConte Glacier, Alaska, USA. Ann. Glaciol., 36, 57-65 (doi: 10.3189/172756403781816374)

Motyka RJ, Truffer M, Fahnestock M, Mortensen J, Rysgaard S and Howat I (2011) Submarine melting of the 1985 Jakobshavn Isbræ floating tongue and the triggering of the current retreat. J. Geophys. Res., 116(F1), F01007 (doi: 10.1029/2009JF001632) Murray T and 10 others (2010) Ocean regulation hypothesis for glacier dynamics in southeast Greenland and implications for ice sheet mass changes. J. Geophys. Res., 115(F3), F03026 (doi: 10.1029/2009JF001522)

Nick FM, Vieli A, Howat IM and Joughin I (2009) Large-scale changes in Greenland outlet glacier dynamics triggered at the terminus. Nature Geosci., 2(2), 110-114 (doi: 10.1038/ngeo394)

Nick FM and 7 others (2013) Future sea-level rise from Greenland's

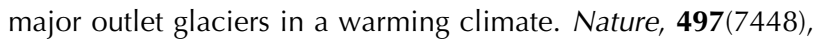
235-238 (doi: 10.1038/nature12068)

Nuth C, Moholdt G, Kohler J, Hagen JO and Kääb A (2010) Svalbard glacier elevation changes and contribution to sea level rise. J. Geophys. Res., 115(F1), F01008 (doi: 10.1029/2008JF001223)

O'Neel S, Pfeffer WT, Krimmel R and Meier M (2005) Evolving force balance at Columbia Glacier, Alaska, during its rapid retreat. J. Geophys. Res., 110(F3), F03012 (doi: 10.1029/ 2005JF000292)

Pavlov VK and Pfirman SL (1995) Hydrographic structure and variability of the Kara Sea: implications for pollutant distribution. Deep-Sea Res. I, 42(6), 1369-1390 (doi: 10.1016/09670645(95)00046-1)

Pfirman SL, Bauch D and Gammelsrød T (1994) The northern Barents Sea: water mass distribution and modification. In Johannessen OM, Muench RD and Overland JE eds. The polar oceans and their role in shaping the global environment: the 
Nansen Centennial volume. (Geophysical Monograph 85) American Geophysical Union, Washington, DC, 77-94

Politova NV, Shevchenko VP and Zernova VV (2012) Distribution, composition, and vertical fluxes of particulate matter in Bays of Novaya Zemlya Archipelago, Vaigach Island at the end of summer. Adv. Meteorol., Art. 259316 (doi: 10.1155/2012/ 259316)

Price SF, Payne AJ, Howat IM and Smith BE (2011) Committed sealevel rise for the next century from Greenland ice sheet dynamics during the past decade. Proc. Natl Acad. Sci. USA (PNAS), 108(22), 8978-8983 (doi: 10.1073/pnas.1017313108)

Pritchard HD, Arthern RJ, Vaughan DG and Edwards LA (2009) Extensive dynamic thinning on the margins of the Greenland and Antarctic ice sheets. Nature, 461(7266), 971-975 (doi: 10.1038/nature08471)

Radić V, Bliss A, Beedlow AC, Hock R, Miles E and Cogley JG (2013) Regional and global projections of twenty-first century glacier mass changes in response to climate scenarios from global climate models. Climate Dyn. (doi: 10.1007/s00382-0131719-7)

Raymond C (1996) Shear margins in glaciers and ice sheets. J. Glaciol., 42(140), 90-102

Reynolds RW, Smith TM, Liu C, Chelton DB, Casey KS and Schlax MG (2007) Daily high-resolution-blended analyses for sea surface temperature. J. Climate, 20(22), 5473-5496 (doi: 10.1175/2007JCLI1824.1)

Rignot E, Box JE, Burgess E and Hanna E (2008) Mass balance of the Greenland ice sheet from 1958 to 2007. Geophys. Res. Lett., 35(20), L20502 (doi: 10.1029/2008GL035417)

Rignot E, Koppes M and Velicogna I (2010) Rapid submarine melting of the calving faces of West Greenland glaciers. Nature Geosci., 3(3), 141-218 (doi: 10.1038/ngeo765)

Seale A, Christoffersen P, Mugford RI and O'Leary M (2011) Ocean forcing of the Greenland ice sheet: calving fronts and patterns of retreat identified by automatic satellite monitoring of eastern outlet glaciers. J. Geophys. Res., 116(F3), F03013 (doi: 10.1029/ 2010JF001847)

Sharov Al (2005) Studying changes of ice coasts in the European Arctic. Geo-Mar. Lett., 25 (2-3), 153-166 (doi: 10.1007/s00367004-0197-7)

Sharov Al, Schöner W and Pail R (2009) Spatial features of glacier changes in the Barents-Kara sector. Geophys. Res. Abstr., 11, 3046 (EGU2009-3046)
Sohn HG, Jezek KC and Van der Veen CJ (1998) Jakobshavn Glacier, West Greenland: 30 years of spaceborne observations. Geophys. Res. Lett., 25(14), 2699-2702 (doi: 10.1029/ 98GL01973

Sole A, Payne T, Bamber J, Nienow P and Krabill W (2008) Testing hypotheses of the cause of peripheral thinning of the Greenland ice sheet: is land-terminating ice thinning at anomalously high rates? Cryos. Discuss., 2(4), 673-710 (doi: 10.5194/tcd-2673-2008)

Solomon S and 7 others eds. (2007) Climate change 2007: the physical science basis. Contribution of Working Group I to the Fourth Assessment Report of the Intergovernmental Panel on Climate Change. Cambridge University Press, Cambridge

Straneo F and 7 others (2010) Rapid circulation of warm subtropical waters in a major glacial fjord in East Greenland. Nature Geosci., 3(33), 182-186 (doi: 10.1038/ngeo764)

Straneo F and 6 others (2011) Impact of fjord dynamics and glacial runoff on the circulation near Helheim Glacier. Nature Geosci. 4(5), 322-327 (doi: 10.1038/ngeo1109)

Thomas RH, Abdalati W, Frederick E, Krabill WB, Manizade S and Steffen K (2003) Investigation of surface melting and dynamic thinning on Jakobshavn Isbræ, Greenland. J. Glaciol., 49(165), 231-239 (doi: 10.3189/172756503781830764)

Thomas R, Frederick E, Krabill W, Manizade S and Martin C (2009) Recent changes on Greenland outlet glaciers. J. Glaciol., 55(189), 147-162 (doi: 10.3189/002214309788608958)

Van den Broeke $M$ and 8 others (2009) Partitioning recent Greenland mass loss. Science, 326(5955), 984-986 (doi: 10.1126/science.1178176)

Vieli A and Nick FM (2011) Understanding and modelling rapid dynamic changes of tidewater outlet glaciers: issues and implications. Surv. Geophys., 32(4-5), 437-458 (doi: 10.1007/ s10712-011-9132-4)

Vieli A, Jania J and Kolondra L (2002) The retreat of a tidewater glacier: observations and model calculations on Hansbreen, Spitsbergen. J. Glaciol., 48(163), 592-600 (doi: 10.3189/ 172756502781831089)

Warren CR and Glasser NF (1992) Contrasting response of South Greenland glaciers to recent climatic change. Arct. Alp. Res., 24(2), 124-132

Zeeberg JJ and Forman SL (2001) Changes in glacier extent on north Novaya Zemlya in the twentieth century. Holocene, 11(2), 161-175 (doi: 10.1191/095968301676173261) 